\title{
Undernutrition, Sarcopenia, and Frailty in Fragility Hip Fracture: Advanced Strategies for Improving Clinical Outcomes
}

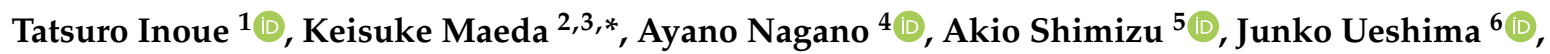 \\ Kenta Murotani ${ }^{7}{ }^{\mathbb{D}}$, Keisuke Sato ${ }^{8}$ and Atsuhiro Tsubaki ${ }^{1}{ }^{1}$ \\ 1 Department of Physical Therapy, Niigata University of Health and Welfare, Shimami-cho 950-3198, Japan; \\ tatsuro-inoue@nuhw.ac.jp (T.I.); tsubaki@nuhw.ac.jp (A.T.) \\ 2 Department of Geriatric Medicine, National Center for Geriatrics and Gerontology, Obu 474-8511, Japan \\ 3 Department of Palliative and Supportive Medicine, Graduate School of Medicine, Aichi Medical University, \\ Nagakute 480-1195, Japan \\ 4 Department of Nursing, Nishinomiya Kyoritsu Neurosurgical Hospital, Nishinomiya 663-8211, Japan; \\ aya.k.nagano@gmail.com \\ 5 Department of Nutrition, Hamamatsu City Rehabilitation Hospital, Hamamatsu 433-8127, Japan; \\ a.shimizu.diet@gmail.com \\ 6 Department of Clinical Nutrition and Food Service, NTT Medical Center Tokyo, Tokyo 141-8625, Japan; \\ j.ueshima@gmail.com \\ 7 Biostatistics Center, Kurume University, Kurume 830-0011, Japan; kmurotani@med.kurume-u.ac.jp \\ 8 Okinawa Chuzan Hospital Clinical Research Center, Chuzan Hospital, Matsumoto 904-2151, Japan; \\ keisuke.sato0815@gmail.com \\ * Correspondence: kskmaeda@ncgg.go.jp; Tel.: +81-561-62-3311; Fax: +81-561-78-6364
}

Received: 31 October 2020; Accepted: 3 December 2020; Published: 4 December 2020

\begin{abstract}
Geriatric patients with hip fractures often experience overlap in problems related to nutrition, including undernutrition, sarcopenia, and frailty. Such problems are powerful predictors of adverse responses, although few healthcare professionals are aware of them and therefore do not implement effective interventions. This review aimed to summarize the impact of undernutrition, sarcopenia, and frailty on clinical outcomes in elderly individuals with hip fractures and identify successful strategies that integrate nutrition and rehabilitation. We searched PubMed (MEDLINE) and Cochrane Central Register of Controlled Trials (CENTRAL) for relevant literature published over the last 10 years and found that advanced interventions targeting the aforementioned conditions helped to significantly improve postoperative outcomes among these patients. Going forward, protocols from advanced interventions for detecting, diagnosing, and treating nutrition problems in geriatric patients with hip fractures should become standard practice in healthcare settings.
\end{abstract}

Keywords: undernutrition; muscular atrophy; frailty syndrome; fragility hip fracture; elderly

\section{Introduction}

Hip fractures are a global public health problem and result in hospitalization, disability, and death [1]. Globally, as the population ages, the number of hip fractures is increasing, and it is expected that 6.3 million people will suffer from hip fracture in 2050 [2]. Hip fracture patients have high mortality [3], experience prolonged disability [4], and require substantial costs for postoperative management [5]. Therefore, management after hip fracture is a critical issue to be resolved.

Hip fracture patients experience multiple geriatric nutritional problems, often including undernutrition, sarcopenia, and frailty at admission, all of which overlap (Figure 1), (Supplementary Figures S1-S3). These geriatric nutritional problems have significant impacts on disability, the occurrence 
of complications, and mortality after hip fracture. Therefore, interventions for these factors are a key strategy for improving postoperative clinical outcomes in patients with hip fracture.

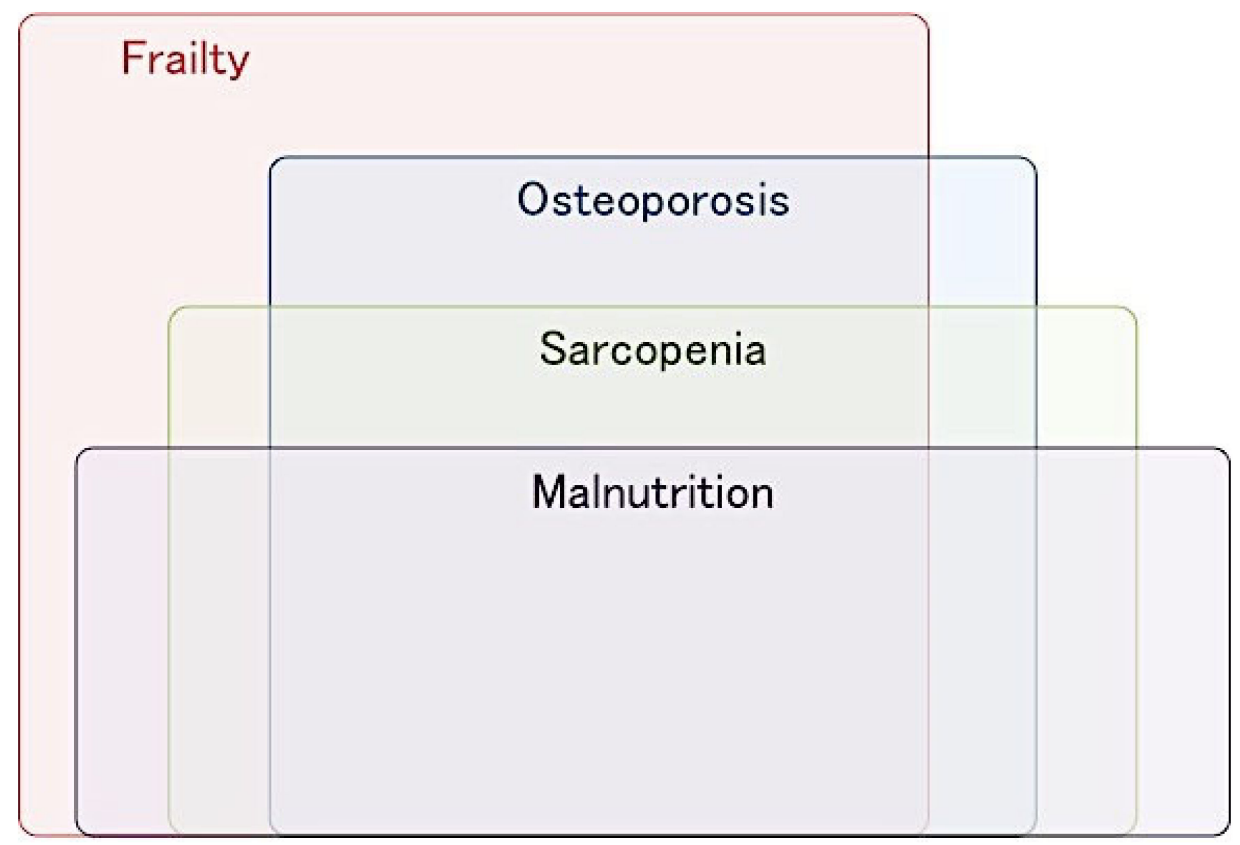

Figure 1. The overlapping geriatric nutritional problems in patients with fragility hip fracture.

Conversely, the effect of interventions for geriatric nutritional problems in patients with hip fracture remains unclear. Nutritional therapy alone was not shown to reduce mortality [6]. Medical professionals often ignore undernutrition, sarcopenia, and frailty, and this unawareness inhibits improvements in clinical outcomes [7]. A focus must be placed on geriatric nutritional problems in hip fracture patients, and effective interventions should be considered. Our review aims to summarize the impact of undernutrition, sarcopenia, and frailty on clinical outcomes and to identify effective interventions combined with nutrition and rehabilitation for hip fracture patients.

\section{Materials and Methods}

\subsection{Data Sources and Search Strategy}

This review adhered to the guidelines of the Preferred Reporting Items for Systematic Reviews and Meta-Analyses (PRISMA) [8]. We searched for relevant literature in PubMed (MEDLINE) and Cochrane Central Register of Controlled Trials (CENTRAL). To review recent studies on undernutrition, sarcopenia, and frailty of patients with hip fracture, we selected observational and intervention studies published in English 10 years since the European Working Group on Sarcopenia in Older People (EWGSOP) was published in 2010 [9]. We used the search terms hip fractures, femoral neck fractures, nutritional status, malnutrition, sarcopenia, muscle atrophy, and frailty.

\subsection{Study Selection}

\subsubsection{Inclusion Criteria}

The inclusion criteria for the included studies in this review were as follows: (1) Assessment of patients with fragility hip fracture; (2) inclusion of both genders and all races; (3) examination of the impact of undernutrition, sarcopenia, and frailty on clinical outcomes; (4) application of validated nutritional assessments, such as nutritional screening tools, anthropometric parameters, and blood concentrations; (5) evaluation of muscle strength and/or muscle mass for diagnosing sarcopenia; (6) utilization of diagnostic criteria that address multiple factors reflecting vulnerability in the absence 
of established diagnostic criteria for frailty; (7) clinical outcomes, such as death, complications, hospital stay, discharge disposition, activities of daily living (ADL), mobility, etc.; and (8) observational and intervention study design.

\subsubsection{Exclusion Criteria}

Editorials, case reports, letters to the editor, review articles, animal studies, and conference abstracts were excluded from this review.

\subsection{Data Extraction}

We extracted the following information from the included studies: Name of the first author, year of publication, country of origin, study design, setting, age, gender prevalence, sample size, screening or assessment tool of nutritional status, diagnostic criteria of sarcopenia and frailty, prevalence of undernutrition, sarcopenia, and frailty, main study outcomes, and main results.

\subsection{Quality Assessment}

We assessed the quality of the included studies using both the National Institutes of Health (NIH) Quality Assessment tool for Observational Cohort and Cross-Sectional Studies and the Quality Assessment of Controlled Intervention Studies [10]. This quality assessment tool comprised 14 items per study design. We scored these items and classified the included studies as "good", "fair", or "poor" (Supplementary Tables S1-S3).

\section{Undernutrition in Patients with Hip Fracture}

\subsection{Prevalence of Undernutrition}

The prevalence of undernutrition with hip fracture is high and varies based on the evaluation tool used, ranging from about $7 \%$ to $26 \%$ (Table 1). The Mini Nutritional Assessment-Short Form (MNA-SF) [11-15] and the Mini Nutritional Assessment-Full Form (MNA-FF) [12,16-19] are the most commonly used tools for evaluating nutritional status in patients with hip fracture. The Malnutrition Screening Tool (MST) [20], Controlling Nutritional Status (CONUT) [21,22], Geriatric Nutritional Risk Index (GNRI) [22,23], Malnutrition Universal Screening Tool (MUST) [24], body mass index (BMI) [25,26], serum albumin [12,16,26,27], prealbumin [27], total protein [27], vitamin D [23,27] and lymphocyte count [16] are also used. These evaluation tools are useful for assessing the nutritional status of patients with hip fracture. 
Table 1. Assessment of nutritional status, prevalence of undernutrition, and the impact of undernutrition on clinical outcomes in patients with hip fracture.

\begin{tabular}{|c|c|c|c|c|c|c|c|}
\hline $\begin{array}{l}\text { Author, Year, } \\
\text { Country }\end{array}$ & Design, Setting & $\begin{array}{c}\text { Age (Years) } \\
\text { Male/Female, } \boldsymbol{n}(\%)\end{array}$ & $\begin{array}{c}\text { Sample } \\
\text { Size }\end{array}$ & $\begin{array}{c}\text { Evaluation Tool } \\
\text { (Timing of Assessment) }\end{array}$ & $\begin{array}{c}\text { Prevalence of } \\
\text { Undernutrition }\end{array}$ & Outcome & Main Results \\
\hline $\begin{array}{l}\text { Miyanishi et al., } \\
2010[26] \\
\text { Japan }\end{array}$ & $\begin{array}{l}\text { Observational } \\
\text { study, acute } \\
\text { hospital }\end{array}$ & $\begin{array}{c}\text { Mean } 79 \\
24(18.9) / 103(81.1)\end{array}$ & 129 & $\begin{array}{l}\text { Serum albumin } \\
\text { BMI }\end{array}$ & Not stated & Four-year mortality & $\begin{array}{l}\text { In, multiple logistic regression analysis, } \\
\text { serum albumin level (OR } 5.854, p<0.001 \text { ) } \\
\text { and BMI (OR } 1.169, p=0.02 \text { ) significantly } \\
\text { influenced mortality. }\end{array}$ \\
\hline $\begin{array}{l}\text { Koren-Hakim et al., } \\
\text { 2012 [13] } \\
\text { Israel }\end{array}$ & $\begin{array}{l}\text { Observational } \\
\text { study, acute } \\
\text { hospital }\end{array}$ & $\begin{array}{l}\text { Mean } 83.5(\text { SD } 6.0) \\
61(28.4) / 154(71.6)\end{array}$ & 215 & $\begin{array}{l}\text { MNA-SF } \\
\text { (at admission and up to } 48 \mathrm{~h} \\
\text { after admission) }\end{array}$ & $\begin{array}{l}\text { Well-nourished: } 44.2 \% \\
\text { At risk: } 44.2 \% \\
\text { Malnourished: } 11.6 \%\end{array}$ & $\begin{array}{l}\text { In-hospital complications } \\
\text { Mortality (up to } 36 \text { months) }\end{array}$ & $\begin{array}{l}\text { Only comorbidity and low functioning can } \\
\text { predict long-term mortality (a minimum of } \\
12 \text { up to } 36 \text { months). } \\
\text { Nutritional status had no effect on outcomes. }\end{array}$ \\
\hline $\begin{array}{c}\text { Gumieiro et al., } 2012 \\
\text { [28] } \\
\text { Brazil }\end{array}$ & $\begin{array}{l}\text { Prospective } \\
\text { observational } \\
\text { study, general } \\
\text { hospital }\end{array}$ & $\begin{array}{l}\text { Mean } 80.2 \text { (SD 7.3) } \\
20(23.3) / 66(76.7)\end{array}$ & 86 & $\begin{array}{c}\text { MNA-FF } \\
\text { NRS-2002 } \\
\text { (within the first } 72 \mathrm{~h} \text { of the } \\
\text { patient's admission) }\end{array}$ & Not stated & $\begin{array}{l}\text { Gait status (patients who } \\
\text { could walk or could not } \\
\text { walk) and mortality at } \\
6 \text { months after hip fracture }\end{array}$ & $\begin{array}{l}\text { In a multivariate analysis, only the MNA-FF } \\
\text { was associated with gait status (OR } 0.773 \text {, } \\
95 \% \text { CI } 0.663-0.901 \text { ) and mortality } 6 \text { months } \\
\text { after hip fracture (HR } 0.869,95 \% \text { CI } \\
0.757-0.998 \text { ). }\end{array}$ \\
\hline $\begin{array}{l}\text { Drevet et al., } 2014 \\
\text { [29] } \\
\text { France }\end{array}$ & $\begin{array}{l}\text { Prospective } \\
\text { observational } \\
\text { study, university } \\
\text { hospital }\end{array}$ & $\begin{array}{l}\text { Mean } 86.1 \text { (SD 4.4) } \\
15(30) / 35(70)\end{array}$ & 50 & $\begin{array}{c}\text { MNA-FF } \\
\text { (no details provided) }\end{array}$ & $\begin{array}{l}\text { At risk for PEM: } 58 \% \\
\text { PEM: } 28 \%\end{array}$ & $\begin{array}{l}\text { Activities of daily living } \\
\text { Hospital stay }\end{array}$ & $\begin{array}{l}\text { PEM was associated with functional } \\
\text { dependence }(p=0.002) \text { and } 8 \text { days longer } \\
\text { mean hospital stay }(p=0.012) \text {. }\end{array}$ \\
\hline $\begin{array}{c}\text { Goisser et al., } 2015 \\
\text { [17] } \\
\text { Germany }\end{array}$ & $\begin{array}{l}\text { Prospective } \\
\text { observational } \\
\text { study, urban } \\
\text { maximum care } \\
\text { hospital }\end{array}$ & $\begin{array}{c}\text { Mean } 84 \text { (SD 5) } \\
(21) /(79)\end{array}$ & 97 & $\begin{array}{l}\text { MNA-FF } \\
\text { (preoperative nutritional } \\
\text { status was evaluated } \\
\text { retrospectively) }\end{array}$ & $\begin{array}{c}\text { At risk: } 38 \% \\
\text { Malnourished: } 17 \%\end{array}$ & Barthel Index after 6 months & $\begin{array}{l}\text { Malnourished patients suffered more from } \\
\text { remaining losses in } \mathrm{ADL} \geq 25 \% \text { of initial } \\
\text { Barthel Index points }(p=0.033) \text {, and } \\
\text { regained their prefracture mobility level to a } \\
\text { lesser extent }(p=0.020) \text { than well-nourished } \\
\text { patients. }\end{array}$ \\
\hline $\begin{array}{c}\text { Bajada et al., } 2015 \\
\text { [16] } \\
\text { UK }\end{array}$ & $\begin{array}{l}\text { Retrospective } \\
\text { observational } \\
\text { study, general } \\
\text { hospital }\end{array}$ & $\begin{array}{l}\text { Mean } 79 \text { years } \\
\text { (range: } 60-96 \text { years) } \\
19(18) / 89(82)\end{array}$ & 108 & $\begin{array}{c}\text { Serum albumin } \\
\text { (normal level }>35 \mathrm{~g} / \mathrm{L} \text { ) } \\
\text { Lymphocyte count }(\text { normal } \\
1-4.5 \times 109 \mathrm{~L}) \\
\text { (on admission) }\end{array}$ & No details provided & Failure of internal fixation & $\begin{array}{l}\text { In binary logistic regression analysis, } \\
\text { lymphocyte count, and albumin levels were } \\
\text { independent predictors of failure of internal } \\
\text { fixation. }\end{array}$ \\
\hline $\begin{array}{l}\text { van Wissen et al., } \\
2016[18] \\
\text { Netherlands }\end{array}$ & $\begin{array}{l}\text { Retrospective } \\
\text { cohort study, } \\
\text { acute hospital }\end{array}$ & $\begin{array}{c}\text { Mean } \\
\text { Malnourished: } 85 \\
\text { (SD 5) } \\
\text { At risk: } 84 \text { (SD 5) } \\
\text { Well-nourished: } 83 \\
\text { (SD 5) } \\
61(27.0) / 165(73.0)\end{array}$ & 226 & $\begin{array}{c}\text { MNA-FF } \\
\text { (before surgery) }\end{array}$ & $\begin{array}{l}\text { Well-nourished: } 4.9 \% \\
\text { At risk: } 26.5 \% \\
\text { Malnourished: } 68.6 \%\end{array}$ & $\begin{array}{c}\text { Hospital stay } \\
\text { Postoperative } \\
\text { complications, Mortality } \\
\text { (in-hospital and 1-year) }\end{array}$ & $\begin{array}{l}\text { Preoperative malnutrition is associated with } \\
\text { in-hospital (OR 4.4; } 95 \% \text { CI 1.0, 20.4) and } \\
\text { 1-year mortality (OR } 2.7 ; 95 \% \text { CI } 1.1,7.0) \text {. } \\
\text { Malnutrition was not associated with any } \\
\text { other outcome. }\end{array}$ \\
\hline $\begin{array}{l}\text { Miu et al., } 2017 \text { [30] } \\
\text { China }\end{array}$ & $\begin{array}{l}\text { Observational } \\
\text { study, } \\
\text { rehabilitation unit }\end{array}$ & $\begin{array}{l}\text { Mean } 83.5(\text { SD 7.5) } \\
74(33.9) / 44(66.1)\end{array}$ & 218 & $\begin{array}{c}\text { MNA-SF } \\
\text { (within } 72 \mathrm{~h} \text { of admission) }\end{array}$ & $\begin{array}{l}\text { Well-nourished: } 21.1 \% \\
\text { At risk: } 52.6 \% \\
\text { Malnourished: } 26.1 \%\end{array}$ & $\begin{array}{l}\text { Functional status and place } \\
\text { of residence at } 6 \text { months } \\
\text { Hospital stay } \\
\text { Mortality (in-hospital, } \\
6 \text { months) }\end{array}$ & $\begin{array}{l}\text { Functional recovery was slower in the } \\
\text { malnourished group. } \\
\text { In-patient mortality was higher in } \\
\text { malnourished patients than in those at risk } \\
\text { of malnourishment and well-nourished } \\
\text { individuals. }\end{array}$ \\
\hline
\end{tabular}


Table 1. Cont

\begin{tabular}{|c|c|c|c|c|c|c|c|}
\hline $\begin{array}{l}\text { Author, Year, } \\
\text { Country }\end{array}$ & Design, Setting & $\begin{array}{c}\text { Age (Years) } \\
\text { Male/Female, } n \text { (\%) }\end{array}$ & $\begin{array}{c}\text { Sample } \\
\text { Size }\end{array}$ & $\begin{array}{c}\text { Evaluation Tool } \\
\text { (Timing of Assessment) }\end{array}$ & $\begin{array}{c}\text { Prevalence of } \\
\text { Undernutrition }\end{array}$ & Outcome & Main Results \\
\hline $\begin{array}{c}\text { Helminen et al., } 2017 \\
\text { [12] } \\
\text { Finland }\end{array}$ & $\begin{array}{l}\text { Prospective } \\
\text { observational } \\
\text { study, acute } \\
\text { hospital }\end{array}$ & $\begin{array}{l}\text { No details provided } \\
169(28.5) / 425(71.5)\end{array}$ & 594 & $\begin{array}{c}\text { MNA-SF } \\
\text { MNA-FF } \\
\text { Serum albumin } \\
\text { (preoperative period) }\end{array}$ & $\begin{array}{c}\text { MNA-SF } \\
\text { Well-nourished: } 53 \% \\
\text { At risk: } 40 \% \\
\text { Malnourished: } 7 \% \\
\text { MNA-FF } \\
\text { Well-nourished: } 35 \% \\
\text { At risk: } 58 \% \\
\text { Malnourished: } 7 \% \\
\text { Serum albumin } \\
\text { <34 g/L: } 46 \%\end{array}$ & $\begin{array}{l}\text { Poorer mobility (transfer to } \\
\text { more assisted living } \\
\text { accommodation) } \\
\text { Mortality (1 month, } \\
4 \text { months, and } 1 \text { year after } \\
\text { fracture) }\end{array}$ & $\begin{array}{l}\text { Risk of malnutrition and malnutrition } \\
\text { measured by MNA-FF predicted mobility } \\
\text { and living arrangements within } 4 \text { months of } \\
\text { hip fracture. } \\
\text { At } 1 \text { year, risk of malnutrition predicted } \\
\text { mobility and malnutrition predicted living } \\
\text { arrangements when measured by the } \\
\text { MNA-FF. } \\
\text { Malnutrition, but not risk measured by the } \\
\text { MNA-SF, predicted living arrangements at } \\
\text { all time points. } \\
\text { Neither measure predicted 1-month mobility. }\end{array}$ \\
\hline $\begin{array}{c}\text { Vosoughi et al., } 2017 \\
\text { [25] } \\
\text { Iran }\end{array}$ & $\begin{array}{l}\text { Cross-sectional } \\
\text { study, university } \\
\text { hospital }\end{array}$ & $\begin{array}{l}\text { Mean } 75.7 \text { (SD 10.6) } \\
318(43.9) / 406(56.1)\end{array}$ & 724 & $\begin{array}{c}\text { BMI } \\
\text { (at admission) }\end{array}$ & No details provided & $\begin{array}{l}\text { Mortality at } 3 \text { months and } \\
1 \text { year }\end{array}$ & $\begin{array}{l}\text { Multivariate logistic regression analysis } \\
\text { recognized age (OR 1.08; } 95 \% \text { CI } 1.05,1.11) \text {, } \\
\text { BMI (OR 0.88; } 95 \% \text { CI 0.82-0.96), and } \\
\text { smoking (OR } 1.76 ; 95 \% \text { CI } 1.05-2.96) \text { as } \\
\text { major independent risk factors for 1- and } \\
\text { 3-year mortality. }\end{array}$ \\
\hline $\begin{array}{c}\text { Mazzola et al., } 2017 \\
\text { [14] } \\
\text { Italy }\end{array}$ & $\begin{array}{l}\text { Prospective } \\
\text { observational } \\
\text { study, university } \\
\text { hospital }\end{array}$ & $\begin{array}{c}\text { Mean 84.0 (SD 6.6) } \\
106(25.5) / 309(74.5)\end{array}$ & 415 & $\begin{array}{c}\text { MNA-SF } \\
\text { (within } 24 \mathrm{~h} \text { of admission) }\end{array}$ & $\begin{array}{l}\text { Well-nourished: } 36.6 \% \\
\text { At risk: } 44.6 \% \\
\text { Malnourished: } 18.8 \%\end{array}$ & Postoperative delirium & $\begin{array}{l}\text { Multivariate regression analysis showed that } \\
\text { those at risk of malnutrition (OR } 2.42 ; 95 \% \mathrm{CI} \\
=1.29-4.53 \text { ) and those overtly malnourished } \\
(\mathrm{OR} 2.98 ; 95 \% \mathrm{CI}=1.43-6.19) \text { were more } \\
\text { likely to develop postoperative delirium. }\end{array}$ \\
\hline $\begin{array}{c}\text { Inoue et al., } 2017 \text { [15] } \\
\text { Japan }\end{array}$ & $\begin{array}{l}\text { Prospective } \\
\text { observational } \\
\text { study, three acute } \\
\text { hospitals }\end{array}$ & $\begin{array}{l}\text { Mean } 82.7 \text { (SD 9.2) } \\
69(10.1) / 165(80.9)\end{array}$ & 204 & $\begin{array}{c}\text { MNA-SF } \\
\text { (first few days after } \\
\text { admission before surgery) }\end{array}$ & $\begin{array}{l}\text { Well-nourished: } 27.0 \% \\
\text { At risk: } 48.0 \% \\
\text { Malnourished: } 25.0 \%\end{array}$ & FIM at discharge & $\begin{array}{l}\text { In multiple regression analyses, MNA-SF } \\
\text { was a significant independent predictor for } \\
\text { FIM at discharge (well-nourished vs. } \\
\text { malnourished, } \beta=0.86, p<0.01 \text { ). }\end{array}$ \\
\hline $\begin{array}{c}\text { Nishioka et al., } 2018 \\
{[11]} \\
\text { Japan }\end{array}$ & $\begin{array}{l}\text { Retrospective } \\
\text { observational } \\
\text { cohort study, } \\
\text { convalescent } \\
\text { rehabilitation units }\end{array}$ & $\begin{array}{l}\text { Mean } 85 \text { years } \\
(21.8) /(78.2)\end{array}$ & 110 & $\begin{array}{c}\text { MNA-SF } \\
\text { (on admission and at } \\
\text { discharge) }\end{array}$ & $\begin{array}{l}\text { Only malnourished } \\
\text { patients at admission } \\
\text { were included }\end{array}$ & $\begin{array}{l}\text { FIM at discharge } \\
\text { Discharged to home }\end{array}$ & $\begin{array}{l}\text { Multivariable analysis revealed a significant } \\
\text { association between improvement in } \\
\text { nutritional status and higher FIM score at } \\
\text { discharge ( } \beta=7.377, p=0.036) \text {. } \\
\text { No association with discharge to home. }\end{array}$ \\
\hline $\begin{array}{c}\text { Stone et al., } 2018 \text { [27] } \\
\text { USA }\end{array}$ & $\begin{array}{l}\text { Retrospective } \\
\text { observational } \\
\text { cohort study, } \\
\text { acute hospital }\end{array}$ & $\begin{array}{c}\text { Not stated } \\
241(39.7) / 366(60.3)\end{array}$ & 607 & $\begin{array}{l}\text { Albumin } \\
\text { Prealbumin } \\
\text { Total protein } \\
\text { Vitamin D }\end{array}$ & Not stated & Thirty-day readmission & $\begin{array}{l}\text { The model incorporated four nutritional } \\
\text { makers (albumin, prealbumin, total protein, } \\
\text { and vitamin D) with an internally } \\
\text { cross-validated C-statistic of } 0.811(95 \% \mathrm{CI} \text {; } \\
0.754,0.867) \text {. }\end{array}$ \\
\hline $\begin{array}{c}\text { Zanetti et al., } 2018 \\
\text { [19] } \\
\text { Italy }\end{array}$ & $\begin{array}{l}\text { Observational } \\
\text { study, acute } \\
\text { hospital }\end{array}$ & $\begin{array}{l}\text { Mean } 84.7 \text { (SD 7.4) } \\
259(21.4) / 952(78.6)\end{array}$ & 1211 & $\begin{array}{l}\text { MNA-FF } \\
\text { (within } 72 \mathrm{~h} \text { from } \\
\text { admission) }\end{array}$ & $\begin{array}{l}\text { Mean MNA-FF score: } \\
22.3 \text { (SD 5.1) }\end{array}$ & $\begin{array}{l}\text { Three, six and } \\
\text { twelve-month mortality }\end{array}$ & $\begin{array}{l}\text { Poor nutritional status was significantly } \\
\text { associated with } 3,6 \text {, and } 12 \text { - month mortality } \\
\text { after adjustment for potential confounders. }\end{array}$ \\
\hline
\end{tabular}


Table 1. Cont

\begin{tabular}{|c|c|c|c|c|c|c|c|}
\hline $\begin{array}{l}\text { Author, Year, } \\
\text { Country }\end{array}$ & Design, Setting & $\begin{array}{c}\text { Age (Years) } \\
\text { Male/Female, } n(\%)\end{array}$ & $\begin{array}{c}\text { Sample } \\
\text { Size }\end{array}$ & $\begin{array}{c}\text { Evaluation Tool } \\
\text { (Timing of Assessment) }\end{array}$ & $\begin{array}{c}\text { Prevalence of } \\
\text { Undernutrition }\end{array}$ & Outcome & Main Results \\
\hline $\begin{array}{c}\text { Kotera et al. } 2019 \\
{[22]} \\
\text { Japan }\end{array}$ & $\begin{array}{l}\text { Retrospective } \\
\text { observational } \\
\text { cohort study, } \\
\text { acute hospitals }\end{array}$ & $\begin{array}{l}\text { Mean } 87 \text { (SD 6) } \\
\text { Not stated }\end{array}$ & 607 & $\begin{array}{l}\text { GNRI } \\
\text { CONUT }\end{array}$ & $\begin{array}{c}\text { GNRI } \\
\text { Normal: } 0.8 \% \\
\text { Light: } 3.0 \% \\
\text { Moderate: } 5.7 \% \\
\text { Severe: } 14.4 \% \\
\text { CONUT } \\
\text { Normal: } 1.6 \% \\
\text { Light: } 2.7 \% \\
\text { Moderate: } 8.1 \% \\
\text { Severe: } 38.9 \%\end{array}$ & Mortality of 180 days & $\begin{array}{l}\text { The GNRI value in the nonsurvivors was } \\
\text { significantly lower than that in the survivors. } \\
\text { The CONUT value in the nonsurvivors was } \\
\text { significantly higher than that in the } \\
\text { survivors. }\end{array}$ \\
\hline $\begin{array}{l}\text { Yagi et al., } 2020 \text { [21] } \\
\text { Japan }\end{array}$ & $\begin{array}{c}\text { Retrospective } \\
\text { observational } \\
\text { cohort study, } \\
\text { community-based }\end{array}$ & $\begin{array}{c}\text { Median } 86 \text { years } \\
\text { (interquartile range } \\
80-90) \\
(19.9) /(80.1)\end{array}$ & 211 & $\begin{array}{c}\text { CONUT } \\
\text { (admission day) }\end{array}$ & $\begin{array}{l}\text { Malnourished } \\
\text { (CONUT score >1): } \\
78.7 \%\end{array}$ & Postoperative complications & $\begin{array}{l}\text { Multivariable analysis found that the } \\
\text { CONUT score was an independent risk } \\
\text { factor for postoperative complications } \\
\text { (OR 1.21; } 95 \% \mathrm{CI}=1.01-1.45) \text {. }\end{array}$ \\
\hline $\begin{array}{l}\text { Hao et al., } 2020 \text { [23] } \\
\text { USA }\end{array}$ & $\begin{array}{c}\text { Retrospective } \\
\text { observational } \\
\text { study (secondary } \\
\text { analysis), } \\
47 \text { sites in North } \\
\text { America }\end{array}$ & $\begin{array}{c}\text { Mean } 82 \text { (SD 7) } \\
(27) /(73)\end{array}$ & 290 & $\begin{array}{c}\text { 25-hydroxyvitamin D } \\
\text { GNRI } \\
\text { (preoperative) }\end{array}$ & $\begin{array}{c}\text { 25-hydroxyvitamin D } \\
\text { (ng/mL) } \\
\geq 30: 17 \% \\
20 \text { to }<30: 37 \% \\
12 \text { to }<20: 34 \% \\
<12: 12 \% \\
\text { GNRI } \\
\text { No risk: } 33 \\
\text { Some risk: } 33 \\
\text { Major/moderate risk: } \\
34\end{array}$ & $\begin{array}{l}\text { Mortality and mobility at } 30 \\
\text { and } 60 \text { days after surgery }\end{array}$ & $\begin{array}{l}\text { Compared with patients with }<12 \mathrm{ng} / \mathrm{mL} \text {, } \\
\text { those with higher } 25(\mathrm{OH}) \mathrm{D} \text { concentrations } \\
\text { had higher rates of walking at } 30 \text { days } \\
(p=0.031): 12 \text { to }<20 \mathrm{ng} / \mathrm{mL} \text { (adjusted OR } \\
2.61 ; 95 \% \text { CI } 1.13,5.99) ; 20 \text { to }<30 \mathrm{ng} / \mathrm{mL} \\
(3.48 ; 1.53,7.95) ; \geq 30 \mathrm{ng} / \mathrm{mL}(2.84 ; 1.12,7.20) \text {. } \\
\text { There was also greater mobility at } 60 \text { days } \\
\text { ( } p=0.028) \text { in patients with higher } 25(\mathrm{OH}) \mathrm{D} \\
\text { compared with the reference group } \\
(<12 \mathrm{ng} / \mathrm{mL}) \text {. } \\
\text { GNRI }<92 \text { showed an overall trend to reduce } \\
\text { mobility (adjusted } p=0.056 \text { ) at } 30 \text { but not at } \\
60 \text { days. } \\
\text { There was no association of vitamin D or } \\
\text { GNRI with mortality at either time. }\end{array}$ \\
\hline $\begin{array}{l}\text { Han et al., } 2020[24] \\
\text { UK }\end{array}$ & $\begin{array}{c}\text { Retrospective } \\
\text { observational } \\
\text { study, National } \\
\text { Health Service } \\
\text { hospital }\end{array}$ & $\begin{array}{l}\text { Mean } 83.8(\text { SD } 8.6) \\
349(28.2) / 890(71.8)\end{array}$ & 1239 & MUST & $\begin{array}{l}\text { Low risk } \\
\text { Medium risk } \\
\text { High risk }\end{array}$ & $\begin{array}{l}\text { Mobilization (starting } \\
\text { rehabilitation within } 1 \text { day } \\
\text { after surgery) } \\
\text { Pressure ulcers } \\
\text { In-patient mortality } \\
\text { Change in discharge } \\
\text { destination }\end{array}$ & $\begin{array}{l}\text { Compared with the well-nourished group, } \\
\text { malnourished individuals showed increased } \\
\text { risk for failure to mobilize within } 1 \text { day of } \\
\text { surgery (OR 1.6; 95\% CI 1.0-2.7), pressure } \\
\text { ulcers (OR 5.5, 95\% CI, 1.8-17.1), in-patient } \\
\text { mortality (OR 2.3; } 95 \% \text { CI, 1.1-4.8), and } \\
\text { discharge to residential/nursing care (OR 2.8; } \\
95 \% \text { CI, 1.2-6.6). }\end{array}$ \\
\hline
\end{tabular}

Abbreviations: BMI, body mass index; OR, odds ratio; SD, standard deviation; MNA-SF, Mini Nutritional Assessment-Short Form; MNA-FF, Mini Nutritional Assessment-Full Form;

NRS-2002, Nutrition Risk Screening 2002; CI, confidence interval; HR, hazard ratio; FIM, Functional Independence Measure; PEM, protein energy malnutrition; ADL, activities of daily living; GNRI, Geriatric Nutritional Risk Index; CONUT, Controlling Nutritional Status; MUST, Malnutrition Universal Screening Tool. 


\subsection{Impact of Undernutrition on Clinical Outcomes}

A large number of observational studies reported a significant association between undernutrition and clinical outcomes in patients with hip fracture. Most studies set mortality $[13,18,19,22-26,28,30]$ or ADL $[11,12,15,17,30]$ as clinical outcomes and the occurrence of postoperative complications [14,18,21,24], length of hospital stay [18,29], discharge disposition [12,24], readmission [27], mobility [23], and failure after internal fixation [16] as additional outcomes. Inoue et al. [15] and Goisser et al. [17] reported that undernutrition, as evaluated via the MNA-SF and MNA-FF, respectively, was a significant predictor of improved ADL at discharge from acute hospitals and six months postsurgery. Nishioka et al. [11] revealed that improvement in nutritional status via MNA-SF screening during hospitalization in a convalescent hospital was associated with ADL at discharge. Miu and Lam [30] reported that, compared with at-risk and well-nourished patients, malnourished patients screened via the MNA-SF had a higher rate of in-hospital mortality. Gumieiro et al. [28] reported that the MNA-FF score was a predictor of mortality after six months. Vosoughi et al. [25] reported that BMI was an independent risk factor of mortality at one and three years. Conversely, Koren-Hakim et al. [13] reported that the MNA-SF score was not associated with mortality at 36 months. Overall, most of the studies found an association between nutritional status and clinical outcomes in hip fracture patients.

Several studies examining the appropriate nutritional screening tools recommended the use of the MNA-SF for hip fracture patients. The European Society for Clinical Nutrition and Metabolism also recommended the MNA-SF and the Malnutrition Universal Screening Tool and the Nutritional Risk Score 2002 (NRS-2002), which is known as a validated nutritional screening tool [31]. In their comparisons of these validated screening tools, Inoue et al. [32] and Koren-Hakim et al. [33] reported that the MNA-SF was a good predictor of ADL at discharge from an acute hospital, readmission during six months, and mortality at 36 months. In a study comparing the MNA-FF and NRS-2002 [28], only the MNA-FF could predict walking ability and mortality after six months. These results suggested that the use of the MNA-SF or MNA-FF is appropriate for predicting clinical outcomes in patients with hip fracture.

\subsection{Highlights of Undernutrition in Hip Fracture}

Evaluation of nutritional status is important, because undernutrition is a significant risk factor for clinical outcomes in hip fracture patients. The MNA-SF and MNA-FF are the most commonly used tools for nutritional status evaluation and were reported to be significant independent predictors of clinical outcomes. The MNA-SF is a simple and quick nutritional screening tool for nutritional status [34]. Furthermore, calf circumference rather than BMI can be used in the scoring of the MNA-SF, which is an advantage because of the difficulty in accurately measuring body weight on admission for patients with hip fracture. Moreover, the scoring for the MNA-SF includes the following components: functional, psychological, and cognitive aspects. Thus, the MNA-SF can accurately reflect the characteristics of elderly patients with hip fracture and might be the most appropriate nutritional screening tool for clinical outcomes in patients with hip fracture.

\section{Sarcopenia in Patients with Hip Fracture}

\subsection{Definition of Sarcopenia}

Sarcopenia is defined as a muscle disease [35,36] characterized by progressive and generalized decreased muscle strength and loss of muscle mass $[9,37]$. Sarcopenia is associated with functional disability, death, and other adverse outcomes [7]. Sarcopenia is also associated with osteoporosis [38] and falls [39], therefore, patients with hip fracture are more likely to be sarcopenic. 


\subsection{Prevalence of Sarcopenia}

The prevalence of sarcopenia is high in patients with hip fracture. Although the prevalence varies on the basis of the diagnostic criteria, the overall prevalence (for both sexes combined) of sarcopenia ranges from $11 \%$ to $76.4 \%$ (Table 2). The prevalence ranges from $12 \%$ to $81 \%$ in males and from $18 \%$ to $76 \%$ in females. The EWGSOP [9], updated EWGSOP2 [37], Asian Working Group for Sarcopenia (AWGS) [40], and updated AWGS 2019 [41] are often used for diagnosis, and the Foundation for the National Institutes of Health [42,43] and SARC-F [44] were also used in reported studies. 
Table 2. Diagnosis criteria of sarcopenia, prevalence, and its impact on clinical outcomes in patients with hip fracture.

\begin{tabular}{|c|c|c|c|c|c|c|c|}
\hline $\begin{array}{l}\text { Author, Year, } \\
\text { Country }\end{array}$ & Design, Setting & $\begin{array}{c}\text { Age } \\
\text { Male/Female, } n(\%)\end{array}$ & $\begin{array}{c}\text { Sample } \\
\text { Size }\end{array}$ & \begin{tabular}{l}
\multicolumn{1}{c}{ Diagnosis Criteria } \\
Measurement Methods of \\
Muscle Strength, Muscle \\
Mass, Physical Function
\end{tabular} & $\begin{array}{l}\text { Prevalence of } \\
\text { Sarcopenia }\end{array}$ & Outcome & Main Results \\
\hline $\begin{array}{l}\text { González-Montalvo } \\
\text { et al., 2015 [45] } \\
\text { Spain }\end{array}$ & $\begin{array}{l}\text { Prospective } \\
\text { observational } \\
\text { study, university } \\
\text { hospital }\end{array}$ & $\begin{array}{l}\text { Mean 85.3 (SD 6.8) } \\
47(20.3) / 382(79.7)\end{array}$ & 479 & $\begin{array}{c}\text { EWGSOP } \\
\text { Handgrip strength } \\
\text { Bioimpedance analysis }\end{array}$ & $17.1 \%$ & Barthel Index at discharge & $\begin{array}{l}\text { In the multivariate analysis, sarcopenia } \\
\text { was not associated with functional } \\
\text { prognosis at discharge (OR 1.68, } 95 \% \text { CI } \\
0.99-2.84 \text { ). }\end{array}$ \\
\hline $\begin{array}{l}\text { Di Monaco et al., } \\
2015 \text { [46] } \\
\text { Italy }\end{array}$ & $\begin{array}{l}\text { Observational } \\
\text { study, } \\
\text { rehabilitation } \\
\text { hospital }\end{array}$ & $\begin{array}{c}\text { Normal: } \\
78.9 \text { (SD 7.7) } \\
\text { Presarcopenia: } \\
73.8 \text { (SD 5.5) } \\
\text { Sarcopenia: } \\
\text { 81.3 (SD 7.5) } \\
\text { All female: } 138(100)\end{array}$ & 138 & $\begin{array}{l}\text { EWGSOP } \\
\text { Handgrip strength } \\
\text { Dual-energy X-ray } \\
\text { absorptiometry }\end{array}$ & $\begin{array}{l}\text { Presarcopenia: } 17 \% \\
\text { Sarcopenia: } 58 \%\end{array}$ & $\begin{array}{l}\text { Barthel Index } \\
\text { (at admission, end of the } \\
\text { rehabilitation course) }\end{array}$ & $\begin{array}{l}\text { Sarcopenia was associated with Barthel } \\
\text { Index scores at the time of assessment } \\
\text { but not at the end of the rehabilitation } \\
\text { course after adjusting for multiple } \\
\text { adjustments }(p<0.001) \text {. }\end{array}$ \\
\hline $\begin{array}{c}\text { Landi et al., } 2017 \\
\text { [43] } \\
\text { Italy }\end{array}$ & $\begin{array}{l}\text { Observational } \\
\text { study, } \\
\text { Geriatric } \\
\text { Rehabilitation Unit } \\
\text { of the hospital }\end{array}$ & $\begin{array}{l}\text { Mean age } 81.3(\mathrm{SD} 4.8) \\
45(36.4) / 82(64.6)\end{array}$ & 127 & $\begin{array}{c}\text { FNIH } \\
\text { Dual-energy X-ray } \\
\text { absorptiometry }\end{array}$ & Sarcopenia: $48 \%$ & $\begin{array}{c}\text { Barthel Index } \\
\text { (at discharge and } 3 \text { months } \\
\text { after discharge) }\end{array}$ & $\begin{array}{l}\text { After adjustment for potential } \\
\text { confounders, participants with } \\
\text { sarcopenia had a significantly increased } \\
\text { risk of incomplete functional recovery } \\
\text { compared with nonsarcopenic patients } \\
\text { (OR 3.07, 95\% CI 1.07-8.75). }\end{array}$ \\
\hline $\begin{array}{l}\text { Di Chang et al., } \\
2018 \text { [47] } \\
\text { Taiwan }\end{array}$ & $\begin{array}{l}\text { Retrospective } \\
\text { observational } \\
\text { study, university } \\
\quad \text { hospital }\end{array}$ & $\begin{array}{c}\text { Mean age } 81.1 \text { (SD } \\
12.2) \\
24(26.4) / 67(73.6)\end{array}$ & 91 & $\begin{array}{c}\text { Computed tomography } \\
\text { (total skeletal muscle area at L4) }\end{array}$ & No details provided & $\begin{array}{c}\text { Hospital stay } \\
\text { Perioperative mortality } \\
\text { Medical complications } \\
\text { In-hospital blood } \\
\text { transfusion volume } \\
\text { Readmission rate at } 90 \text { days }\end{array}$ & $\begin{array}{l}\text { Low skeletal muscle index was } \\
\text { independently associated with longer } \\
\text { length of hospitalization }(p=0.032) \text { but } \\
\text { was not associated with any other } \\
\text { outcomes. }\end{array}$ \\
\hline $\begin{array}{c}\text { Kim et al., } 2018 \\
\text { [48] } \\
\text { Korea }\end{array}$ & $\begin{array}{l}\text { Retrospective } \\
\text { observational } \\
\text { study, National } \\
\text { Police Hospital }\end{array}$ & $\begin{array}{l}\text { Mean 78.5 years } \\
\text { (range, 65-94 years) } \\
27(29.7) / 64(70.3)\end{array}$ & 91 & $\begin{array}{l}\text { Choi et al. reported criteria } \\
\text { Computed tomography } \\
\text { (L3) }\end{array}$ & $49.5 \%$ & $\begin{array}{l}\text { One-year and five-year } \\
\text { mortality rates }\end{array}$ & $\begin{array}{l}\text { Kaplan-Meier analysis showed that } \\
\text { sarcopenia did not affect the } 1 \text {-year } \\
\text { mortality rate }(p=0.793) \text { but had a } \\
\text { significant effect on the 5-year mortality } \\
\text { rate }(p=0.028) \text {. } \\
\text { Both perioperative sarcopenia }(p=0.018) \\
\text { and osteoporosis }(p<0.001) \text { affected the } \\
\text { 5-year mortality rate. }\end{array}$ \\
\hline $\begin{array}{l}\text { Yoo et al., } 2018[49] \\
\text { Korea }\end{array}$ & $\begin{array}{l}\text { Retrospective } \\
\text { observational } \\
\text { study, university } \\
\quad \text { hospital }\end{array}$ & $\begin{array}{l}\text { Mean 77.8 (SD 9.7) } \\
78(24.1) / 246(75.9)\end{array}$ & 324 & $\begin{array}{c}\text { AWGS } \\
\text { Handgrip strength } \\
\text { Dual-energy X-ray } \\
\text { absorptiometry }\end{array}$ & $37.7 \%$ & One-year mortality & $\begin{array}{l}\text { Osteosarcopenia }(15.1 \% \text { ) was higher for } \\
\text { 1-year mortality than other groups } \\
\text { (normal: } 7.8 \% \text {, osteoporosis alone: } 5.1 \% \text {, } \\
\text { sarcopenia alone: } 10.3 \% \text { ). }\end{array}$ \\
\hline
\end{tabular}


Table 2. Cont.

\begin{tabular}{|c|c|c|c|c|c|c|c|}
\hline $\begin{array}{l}\text { Author, Year, } \\
\text { Country }\end{array}$ & Design, Setting & $\begin{array}{c}\text { Age } \\
\text { Male/Female, } n \text { (\%) }\end{array}$ & $\begin{array}{c}\text { Sample } \\
\text { Size }\end{array}$ & \begin{tabular}{l}
\multicolumn{1}{c}{ Diagnosis Criteria } \\
Measurement Methods of \\
Muscle Strength, Muscle \\
Mass, Physical Function
\end{tabular} & $\begin{array}{l}\text { Prevalence of } \\
\text { Sarcopenia }\end{array}$ & Outcome & Main Results \\
\hline $\begin{array}{l}\text { Steihaug et al., } \\
2018 \text { [50] } \\
\text { Norway }\end{array}$ & $\begin{array}{l}\text { Prospective } \\
\text { observational } \\
\text { study, acute } \\
\text { hospital } \\
\text { (three hospitals) }\end{array}$ & $\begin{array}{c}\text { Mean } 79.4 \text { (SD 8.2) } \\
(24) /(76)\end{array}$ & 282 & $\begin{array}{c}\text { EWGSOP } \\
\text { Handgrip strength } \\
\text { The formula reported by } \\
\text { Heymsfield et al. (using gender, } \\
\text { height, arm circumference, and } \\
\text { triceps skinfold) } \\
\text { New Mobility Score }\end{array}$ & $38 \%$ & $\begin{array}{c}\text { Change in New Mobility } \\
\text { Score } \\
\text { Resident of a nursing home } \\
\text { Death }\end{array}$ & $\begin{array}{l}\text { Sarcopenia did not predict change in } \\
\text { mobility }(p=0.6), \text { but it was associated } \\
\text { with having lower mobility at } 1 \text {-year } \\
\text { ( } p=0.003) \text {, becoming a resident of a } \\
\text { nursing home (OR } 3.2, p=0.048) \text {, and the } \\
\text { combined endpoint of becoming a } \\
\text { resident of a skilled nursing home or } \\
\text { death (OR } 3.6, p=0.02 \text { ). }\end{array}$ \\
\hline $\begin{array}{l}\text { Malafarina et al., } \\
2019 \text { [51] } \\
\text { Spain }\end{array}$ & $\begin{array}{l}\text { Prospective } \\
\text { observational } \\
\text { study, two } \\
\text { rehabilitation units }\end{array}$ & $\begin{array}{l}\text { Mean 85.2 (SD 6.3) } \\
49(26.2) / 138(73.8)\end{array}$ & 187 & $\begin{array}{c}\text { EWGSOP2 } \\
\text { Handgrip strength } \\
\text { Bioimpedance analysis } \\
4 \text { meter walking test }\end{array}$ & $\begin{array}{c}\text { Incident sarcopenia } \\
\text { during hospitalization: } \\
54 \text { patients } \\
\text { Sarcopenia at admission } \\
\text { and at discharge } \\
\text { (chronic sarcopenia): } 41 \\
\text { patients } \\
\text { Sarcopenic at admission } \\
\text { but reverted sarcopenia } \\
\text { during the admission } \\
\text { period (reverted } \\
\text { sarcopenia): } 17 \text { patients }\end{array}$ & Mortality after 7 years & $\begin{array}{l}\text { Cox regression analyses showed that } \\
\text { sarcopenia was a risk factor for mortality } \\
\text { (HR: } 1.67,95 \% \text { CI 1.11-2.51) and low } \\
\text { handgrip strength (HR: } 1.76,95 \% \text { CI } \\
\text { 1.08-2.88). }\end{array}$ \\
\hline $\begin{array}{c}\text { Byun et al., } 2019 \\
\text { [52] } \\
\text { Korea }\end{array}$ & $\begin{array}{l}\text { Retrospective } \\
\text { study, university } \\
\text { hospital }\end{array}$ & $\begin{array}{r}\text { Mean 78.4 (SD 9.7) } \\
121(24.5) / 373(75.5)\end{array}$ & 494 & $\begin{array}{c}\text { AWGS } \\
\text { Handgrip strength } \\
\text { Computed tomography } \\
\text { (psoas cross-sectional area at } \\
\text { L4-L5 level) }\end{array}$ & No details provided & One-year mortality & $\begin{array}{l}\text { After adjusting for potential } \\
\text { confounders, the lowest quintile of psoas } \\
\text { cross-sectional area was significantly } \\
\text { associated with mortality only in females } \\
\text { (HR 1.76, 95\% CI 1.05-2.70). }\end{array}$ \\
\hline $\begin{array}{c}\text { Chen et al., } 2020 \\
\text { [53] } \\
\text { Hong Kong }\end{array}$ & $\begin{array}{l}\text { Prospective } \\
\text { observational } \\
\text { study, acute } \\
\text { hospital }\end{array}$ & $\begin{array}{c}\text { Mean 80.72 (SD 9.66) } \\
36(25.9) / 103(74.1)\end{array}$ & 139 & $\begin{array}{c}\text { AWGS } \\
\text { Handgrip strength } \\
\text { Dual-energy X-ray } \\
\text { absorptiometry }\end{array}$ & $50.36 \%$ & $\begin{array}{l}\text { EQ5D and Barthel Index at } \\
6 \text { months after the operation }\end{array}$ & $\begin{array}{l}\text { After } 6 \text { months, patients with sarcopenia } \\
\text { had a poor Barthel Index and a lower } \\
\text { EQ5D than patients without sarcopenia } \\
\text { before injury. }\end{array}$ \\
\hline $\begin{array}{l}\text { Chiles Shaffer et } \\
\text { al., } 2020 \text { [54] } \\
\text { USA }\end{array}$ & $\begin{array}{l}\text { Prospective } \\
\text { observational } \\
\text { study, the seventh } \\
\text { cohort of the } \\
\text { Baltimore Hip } \\
\text { Studies }\end{array}$ & $\begin{array}{c}\text { Male: } 81.0 \text { (SD 7.5) } \\
\text { Female: } 80.2 \text { (SD 7.6) } \\
82(51.3) / 78(48.7)\end{array}$ & 160 & $\begin{array}{c}\text { EWGSOP } \\
\text { IWGS } \\
\text { FNIH } \\
\text { Handgrip strength } \\
\text { Dual-energy X-ray } \\
\text { absorptiometry } \\
\text { Gait speed }\end{array}$ & No details provided & $\begin{array}{l}\text { Sarcopenia prevalence over } \\
12 \text { months after hip fracture }\end{array}$ & $\begin{array}{l}\text { Sarcopenia prevalence was stable over } \\
\text { time in men by all definitions, whereas } \\
\text { the prevalence in women by FNIH was } \\
\text { lowest at } 2 \text { months, significantly } \\
\text { increased at } 6 \text { months }(p=0.03) \text { and } \\
\text { remained higher at } 12 \text { months. } \\
\text { Sarcopenia prevalence differed } \\
\text { significantly by sex and varied by time } \\
\text { point and definition; however, when } \\
\text { different, men had a higher prevalence } \\
\text { than women did }(p<0.05) \text {. }\end{array}$ \\
\hline
\end{tabular}


Table 2. Cont.

\begin{tabular}{|c|c|c|c|c|c|c|c|}
\hline $\begin{array}{l}\text { Author, Year, } \\
\text { Country }\end{array}$ & Design, Setting & $\begin{array}{c}\text { Age } \\
\text { Male/Female, } n(\%)\end{array}$ & $\begin{array}{l}\text { Sample } \\
\text { Size }\end{array}$ & $\begin{array}{l}\quad \text { Diagnosis Criteria } \\
\text { Measurement Methods of } \\
\text { Muscle Strength, Muscle } \\
\text { Mass, Physical Function }\end{array}$ & $\begin{array}{l}\text { Prevalence of } \\
\text { Sarcopenia }\end{array}$ & Outcome & Main Results \\
\hline $\begin{array}{c}\text { Shin et al., } 2020 \\
\text { [55] } \\
\text { Korea }\end{array}$ & $\begin{array}{c}\text { Retrospective } \\
\text { cohort study, } \\
\text { university } \\
\text { Hospital }\end{array}$ & $\begin{array}{c}\text { Mean age } 74.1 \\
(\text { range, } 25-96) \\
35(25.9) / 100(74.1)\end{array}$ & 135 & $\begin{array}{c}\text { AWGS } \\
\text { Dual-energy X-ray } \\
\text { absorptiometry }\end{array}$ & $45.9 \%$ & $\begin{array}{l}\text { Harris Hip Score } \\
\text { Parker's mobility score at } \\
\text { the last follow-up } \\
\text { Discharge disposition }\end{array}$ & $\begin{array}{l}\text { In multiple regression analysis, no } \\
\text { significant association was found } \\
\text { between sarcopenia and the Harris Hip } \\
\text { Score of mobility at the last follow-up, } \\
\text { nonunion, or time to union. }\end{array}$ \\
\hline $\begin{array}{c}\text { Nagano et al., } 2020 \\
{[56]} \\
\text { Japan }\end{array}$ & $\begin{array}{l}\text { Retrospective } \\
\text { observational } \\
\text { study, acute } \\
\text { hospital }\end{array}$ & $\begin{array}{l}\text { Mean } 85.9 \text { (SD 6.5) } \\
\text { All female patients, } \\
89 \text { (100) }\end{array}$ & 89 & $\begin{array}{c}\text { AWGS } 2019 \\
\text { Handgrip strength } \\
\text { Bioimpedance analysis }\end{array}$ & $76.4 \%$ & $\begin{array}{l}\text { Incidence of dysphagia on } \\
\text { day } 7 \text { and discharge }\end{array}$ & $\begin{array}{l}\text { All patients who developed dysphagia } \\
\text { had underlying sarcopenia. }\end{array}$ \\
\hline $\begin{array}{l}\text { Ha et al., } 2020[57] \\
\text { Korea }\end{array}$ & $\begin{array}{l}\text { Cross-sectional } \\
\text { study, acute } \\
\text { hospital }\end{array}$ & $\begin{array}{c}\text { Not sarcopenia: } 76.02 \\
\text { (SD 6.87) } \\
\text { Sarcopenia: } 82.62 \text { (SD } \\
7.72) \\
22(19.1) / 93(80.9)\end{array}$ & 115 & $\begin{array}{c}\text { SARC-F, EWGSSOP2, AWGS, } \\
\text { IWGS } \\
\text { Handgrip strength } \\
\text { Dual-energy X-ray } \\
\text { absorptiometry }\end{array}$ & $\begin{array}{l}\text { SARC-F: } 63.5 \% \\
\text { EWGS2: } 43(37.4 \%) \\
\text { AWGS: } 35(30.4 \%) \\
\text { IWGS: } 60(52.2 \%)\end{array}$ & $\begin{array}{l}\text { Comparison of the results } \\
\text { with criteria }\end{array}$ & $\begin{array}{l}\text { Accuracy of SARC-F was that the } \\
\text { sensitivity, specificity, positive predictive } \\
\text { value, negative predictive value, and } \\
\text { positive predictive value with the } \\
\text { EWGSOP2 criteria as the reference } \\
\text { standard were } 95.35 \%, 56.94 \%, 56.94 \% \text {, } \\
95.35 \% \text {, and } 71.3 \% \text {, respectively. }\end{array}$ \\
\hline
\end{tabular}

Abbreviations: EWGSOP, European Working Group on Sarcopenia in Older People; OR, odds ratio; CI, confidence interval; FNIH, Foundation for the National Institutes of Health; AWGS,

Asian Working Group for Sarcopenia; IWGS, International Working Group on Sarcopenia; HR, hazard ratio. 
Previous studies reported two ways to diagnose sarcopenia, i.e., using either a combination of muscle strength and muscle mass [45,46,49-54,56-63] or muscle mass alone [43,47,48,55]. In all of the studies referenced in the present review, handgrip strength was used to evaluate muscle strength. Dual-energy X-ray absorptiometry $[43,46,49,53-55,57]$ and bioimpedance analysis (BIA) $[45,51,56,60,62,63]$ were mostly used to evaluate muscle mass, with computed tomography $[47,52]$ and anthropometric measurement [50,58] also used. Postoperative hip fracture patients have implantation of metal in the lower extremity, and the BIA may overestimate the muscle mass of the operative lower extremity because of its methodological limitations. Therefore, whether BIA is a suitable method for measuring muscle mass in patients with hip fractures is unclear. The criteria for sarcopenia diagnosis are becoming standardized, and further research using standardized diagnostic criteria is necessary in patients with hip fracture.

\subsection{Impact of Sarcopenia on Clinical Outcomes}

Most observational studies reported a significant association between sarcopenia and clinical outcomes in patients with hip fractures. Many studies set outcomes for mortality [48,50-52] and ADL $[43,46]$. Others reported an association between sarcopenia and mobility [50], quality of life (QOL) [53], length of hospital stay [47], discharge disposition [50], and the development of dysphagia [56]. Di Monaco et al. [46] reported the association between sarcopenia and ADL at admission to a convalescent hospital. Landi et al. [43] reported the association between sarcopenia and ADL at discharge from a rehabilitation hospital and after 3 months, and Steihaug et al. [50] reported the association between sarcopenia and mobility after 1 year. Nagano et al. [56] reported an association between sarcopenia and the development of dysphagia after hip fracture. Regarding mortality, Kim et al. [48] reported that sarcopenia was not associated with mortality at one year postoperatively but was associated with mortality at five years. Conversely, Byun et al. [52] reported an association between sarcopenia in women and one-year mortality. Malafarina et al. [51] reported sarcopenia was a predictor of mortality at seven years. Overall, sarcopenia was found to be a significant independent predictor of postoperative clinical outcomes, and the diagnosis of sarcopenia is important to improve clinical outcomes.

\subsection{Highlights of Sarcopenia in Hip Fracture}

The prevalence of sarcopenia is very high, and sarcopenia is a significant predictor of adverse outcomes in patients with hip fractures. The diagnostic criteria of the EWGSOP, updated EWGSOP2, AWGS, and updated AWGS 2019 are mainly used for the diagnosis of sarcopenia, depending on the race of the patients. The use of standardized diagnostic criteria has had a positive impact on the increase in sarcopenia research in patients with hip fracture. However, sarcopenia is often overlooked in clinical practice [7], and there are no intervention studies in hip fracture patients with sarcopenia. Thus, this type of study in hip fracture patients with sarcopenia is strongly needed.

\section{Frailty in Patients with Hip Fracture}

\subsection{Definition of Frailty}

Frailty is defined as a state of vulnerability accompanied by various preliminary reductions in the ability to maintain or regain homeostasis when exposed to stressors [64]. However, no standardized diagnostic criteria of frailty exist, and various tools were used in reported studies [64-66]. A previous study reported an association between frailty and the incidence of hip fractures [67], with a large proportion of hip fracture patients expected to have frailty.

\subsection{Prevalence of Frailty}

The diagnosis of frailty in patients with hip fracture is hindered by a lack of standardized diagnostic criteria for frailty. These criteria vary in the studies referenced in the present review (Table 3). 
Therefore, discussing the prevalence of frailty in hip fracture patients is difficult. The most commonly used criteria are the frailty phenotype reported by Fried et al. [68] and the frailty index reported by Rockwood et al. [69]. Frailty phenotype has the following five features or criteria: Weakness, slow gait speed, low physical activity, exhaustion, and unintentional weight loss [68]. Frailty is diagnosed if a positive score is obtained for three or more symptoms or signs out of the five criteria. 
Table 3. Diagnosis criteria of frailty and its prevalence and impact on clinical outcomes in patients with hip fracture.

\begin{tabular}{|c|c|c|c|c|c|c|c|}
\hline $\begin{array}{l}\text { Author, Year, } \\
\text { Country }\end{array}$ & $\begin{array}{l}\text { Design, } \\
\text { Setting }\end{array}$ & $\begin{array}{c}\text { Age } \\
\text { Male/Female, } n(\%)\end{array}$ & $\begin{array}{c}\text { Sample } \\
\text { Size }\end{array}$ & $\begin{array}{l}\text { Diagnosis Criteria } \\
\text { Details of Criteria }\end{array}$ & Prevalence of Frailty & Outcome & Main Results \\
\hline $\begin{array}{c}\text { Patel et al., } 2014 \\
{[70]} \\
\text { USA }\end{array}$ & $\begin{array}{c}\text { Retrospective } \\
\text { observational } \\
\text { study, acute } \\
\text { hospital }\end{array}$ & $\begin{array}{c}\text { Mean } 81.05 \text { (SD 8.45) } \\
\text { No gender details } \\
\text { provided }\end{array}$ & 697 & $\begin{array}{c}\text { Modified frailty index } \\
19 \text { items } \\
\text { Comorbidities, cognitive function, } \\
\text { and walking ability } \\
\text { Frailty index }\end{array}$ & No details provided & $\begin{array}{c}\text { One-year and } \\
\text { two-year mortality } \\
\text { rates after femoral } \\
\text { neck fracture }\end{array}$ & $\begin{array}{l}\text { Patients with a modified frailty index had an } \\
\text { OR of } 4.97 \text { for 1-year mortality and an OR of } \\
4.01 \text { for 2-year mortality as compared with } \\
\text { patients with an index less than } 4 .\end{array}$ \\
\hline $\begin{array}{l}\text { Krishnan et al., } \\
\text { 2014 [71] } \\
\text { UK }\end{array}$ & $\begin{array}{l}\text { Prospective study, } \\
\text { university-affiliated } \\
\text { community } \\
\text { hospital }\end{array}$ & $\begin{array}{c}\text { Mean } 81 \\
\text { (range, } 47-101) \\
47(26.5) / 131(735)\end{array}$ & 178 & $\begin{array}{c}\text { Fifty-one deficits } \\
\text { Motivation, self-rated health, } \\
\text { cognitive assessments, clock face } \\
\text { drawing, comorbidities, continence, } \\
\text { mobility, and functional } \\
\text { independence } \\
\text { Low-frailty group (FI } \leq 0.25 \text { ), } \\
\text { intermediate (FI }>0.25-0.4) \text {, high-FI } \\
\text { group }(\mathrm{FI}>0.4)\end{array}$ & $\begin{array}{c}\text { Low-frailty group (FI } \leq \\
0.25): 56(31.5 \%) \\
\text { Intermediate (FI } \\
>0.25-0.4): 58(32.5 \%) \\
\text { High (FI }>0.4): 64(36 \%)\end{array}$ & $\begin{array}{c}\text { Hospital stay } \\
\text { Discharge disposition }\end{array}$ & $\begin{array}{l}\text { The mean length of hospital stay for the } \\
\text { intermediate group was } 36.3 \text { days in the } \\
\text { high-FI group compared with } 67.8 \text { days in } \\
\text { the high-FI group }(p<0.01) \text {. } \\
30 \text {-day mortality was } 3.4 \% \text { for the } \\
\text { intermediate group compared with } 17.2 \% \text { for } \\
\text { the high-FI group }(p<0.001) \text {. }\end{array}$ \\
\hline $\begin{array}{c}\text { Kistler et al., } 2015 \\
{[72]} \\
\text { USA }\end{array}$ & $\begin{array}{l}\text { Prospective } \\
\text { observational } \\
\text { study, } \\
\text { university-affiliated } \\
\text { community } \\
\text { hospital }\end{array}$ & $\begin{array}{c}\text { Mean } 86 \text { (SD 4) } \\
6(17) / 29(83)\end{array}$ & 35 & $\begin{array}{l}\text { Fried frailty index (modified for a } \\
\text { post fracture population) } \\
\text { Shrinking, exhaustion, slowness, } \\
\text { weakness, and physical activity } \\
\text { Participants with a total score of } 3 \\
\text { or higher were considered frail }\end{array}$ & $51 \%$ & $\begin{array}{l}\text { Overall hospital } \\
\text { complication rate } \\
\text { Hospital stay } \\
\text { Complications }\end{array}$ & $\begin{array}{l}\text { Frail patients }(67 \%) \text { versus nonfrail patients } \\
(29 \%) \text { had a complication }(p=0.028) \text {. } \\
\text { Mean length of stay was longer in patients } \\
\text { with frailty }(7.3 \text { (SD) } 5.9 \text { vs. } 4.1 \text { (SD) } 1.2 \text { days } \\
p=0.038) \text {. }\end{array}$ \\
\hline $\begin{array}{c}\text { Gleason et al., } 2017 \\
{[73]} \\
\text { USA }\end{array}$ & $\begin{array}{l}\text { Retrospective } \\
\text { observational } \\
\text { study, acute } \\
\text { hospital }\end{array}$ & $\begin{array}{l}\text { Mean 82.3 (SD 7.4) } \\
44(25.1) / 131(74.9)\end{array}$ & 175 & $\begin{array}{l}\text { The FRAIL scale } \\
\text { Five-question assessment } \\
\text { Fatigue, resistance, aerobic capacity, } \\
\text { illnesses, and loss of weight } \\
\text { Classified the patients into three } \\
\text { categories: robust (score }=0 \text { ), } \\
\text { prefrail (score }=1-2) \text {, and frail } \\
\text { (score }=3-5)\end{array}$ & $\begin{array}{c}\text { Robust }(n=29): 16.6 \% \\
\text { Prefrail }(n=73): 41.7 \% \\
\text { Frail }(n=73): 41.7 \%\end{array}$ & $\begin{array}{l}\text { Postoperative } \\
\text { complications } \\
\text { Unplanned intensive } \\
\text { care unit admission } \\
\text { Hospital stay } \\
\text { Discharge disposition } \\
\text { 30-day readmission } \\
\text { and mortality }\end{array}$ & $\begin{array}{l}\text { There was a statistically significant } \\
\text { association between frailty and both length } \\
\text { of stay }(4.2,5.0, \text { and } 7.1 \text { days, } p=002, \text { in } \\
\text { robust, prefrail, and frail groups) and the } \\
\text { development of any complication ( } 3.4 \% \text {, } \\
26 \% \text {, and } 39.7 \%, p=0.03 \text { ) after surgery. } \\
\text { There were also significant differences in } \\
\text { discharge disposition ( } 31 \% \text { of robust vs. } 4.1 \% \\
\text { frailty, } p=0.008 \text { ) and follow-up completion } \\
(97 \% \text { of robust vs. } 69 \% \text { of frail). } \\
\text { High-risk patients showed a higher risk of } \\
\text { six-month mortality (HR: } 3.545,95 \% \text { CI: } \\
1.466-8.572) \text { than low-risk patients after } \\
\text { adjustment. }\end{array}$ \\
\hline $\begin{array}{c}\text { Choi et al., } 2017 \\
\text { [74] } \\
\text { Korea }\end{array}$ & $\begin{array}{c}\text { Retrospective } \\
\text { study, university } \\
\text { hospital }\end{array}$ & $\begin{array}{c}\text { Mean 80.4 } \\
\text { (IQR 75.3-85.3) } \\
139(28.8) / 343(71.3)\end{array}$ & 481 & $\begin{array}{l}\text { Hip-Multidimensional Frailty Score } \\
\text { Sex, Charlson Comorbidity Index, } \\
\text { Albumin, Koval grade, risk of } \\
\text { falling, MNA, and mid-arm } \\
\text { circumference } \\
\text { High risk: }>8 \text { and low risk: } \leq 8\end{array}$ & High risk: $24.3 \%$ & $\begin{array}{l}\text { One-year all-cause } \\
\text { mortality } \\
\text { Postoperative } \\
\text { complication } \\
\text { Hospital stay } \\
\text { Institutionalization }\end{array}$ & $\begin{array}{l}\text { Hip-Multidimensional Frailty Score could } \\
\text { predict six-month mortality, postoperative } \\
\text { complications, and prolonged hospital stay } \\
\text { after surgery. } \\
\text { Hip-Multidimensional Frailty Score more } \\
\text { precisely predicted six-month mortality than } \\
\text { age or existing tools ( } p \text { values of comparison } \\
\text { of ROC curve: } 0.002,0.004 \text {, and } 0.044 \text { for the } \\
\text { ASA classification, age, and NHFS, } \\
\text { respectively). }\end{array}$ \\
\hline
\end{tabular}


Table 3. Cont.

\begin{tabular}{|c|c|c|c|c|c|c|c|}
\hline $\begin{array}{l}\text { Author, Year, } \\
\text { Country }\end{array}$ & $\begin{array}{l}\text { Design, } \\
\text { Setting }\end{array}$ & $\begin{array}{c}\text { Age } \\
\text { Male/Female, } n(\%)\end{array}$ & $\begin{array}{c}\text { Sample } \\
\text { Size }\end{array}$ & $\begin{array}{l}\text { Diagnosis Criteria } \\
\text { Details of Criteria }\end{array}$ & Prevalence of Frailty & Outcome & Main Results \\
\hline $\begin{array}{c}\text { Winters et al., } 2108 \\
{[75]} \\
\text { Netherlands }\end{array}$ & $\begin{array}{l}\text { Retrospective } \\
\text { observational } \\
\text { cohort study, } \\
\text { general hospital }\end{array}$ & $\begin{array}{l}\text { Mean } 83.0 \text { (SD 6.6) } \\
71(25) / 215(75)\end{array}$ & 280 & $\begin{array}{l}\text { Groningen Frailty Indicator } \\
\text { questionnaire } \\
\text { Consisted of } 15 \text { questions } \\
\text { Physical, cognitive, social, and } \\
\text { psychological impairments } \\
\text { Score on a scale of 0-15 } \\
\text { Score of } 4 \text { or higher suggests frailty } \\
\text { VeiligheidsManagementSysteem } \\
\text { Three items (cognitive impairment } \\
\text { or confusion during earlier } \\
\text { admissions, falls in the last } \\
6 \text { months, and physical } \\
\text { impairments) } \\
\text { Falling and another question to }\end{array}$ & $\begin{array}{c}\text { Groningen Frailty } \\
\text { Indicator questionnaire: } \\
60 \% \\
\text { VeiligheidsManagement } \\
\text { Systeem: } \\
58 \%\end{array}$ & $\begin{array}{l}\text { Mortality 3-years and } \\
30 \text { days after surgery }\end{array}$ & $\begin{array}{l}\text { VMS showed a statistically significant } \\
\text { difference in overall survival as compared to } \\
\text { nonfrail patients ( } 57 \text { vs } 80 \% \text {, respectively, } \\
p<0.001) \text { with an HR of } 3.5 \text { ( } 95 \% \text { CI } 2.1-5.7 \text {; } \\
p<0.001) \text { ). Classification according to GFI } \\
\text { yeilded a lower but still significant HR } 2.3 \\
(95 \% \text { CI 1.2-4.1; } p=0.008) \text {. }\end{array}$ \\
\hline $\begin{array}{c}\text { Vasu et al., } 2018 \\
{[76]} \\
\text { India }\end{array}$ & $\begin{array}{l}\text { Retrospective } \\
\text { observational } \\
\text { study, } \\
\text { acute hospital }\end{array}$ & $\begin{array}{c}\text { Not stated } \\
34(56.7) / 26(43.3)\end{array}$ & 60 & $\begin{array}{l}\text { determine the frailty } \\
\text { Modified frailty index } \\
\text { Nineteen items } \\
\text { Comorbidities, cognitive function, } \\
\text { and walking ability }\end{array}$ & $\begin{array}{l}\text { Mean modified frailty } \\
\text { index score: } 3\end{array}$ & 90 days mortality & $\begin{array}{l}\text { Modified frailty index } \\
\text { and } 90 \text {-day mortality showed a significantly } \\
\text { direct correlation, with }<0.001 \text {. }\end{array}$ \\
\hline $\begin{array}{c}\text { Chen et al., } 2019 \\
\text { [77] } \\
\text { Taiwan }\end{array}$ & $\begin{array}{l}\text { Prospective } \\
\text { observational } \\
\text { cohort study }\end{array}$ & $\begin{array}{c}\leq 75: 34.3 \% \\
76-85: 41.2 \% \\
\geq 86: 25.5 \% \\
79(32.2) / 166(67.8)\end{array}$ & 245 & $\begin{array}{l}\text { Chinese-Canadian Study of Health } \\
\text { and Aging Clinical Frailty Scale } \\
\text { Ranged from } 1 \text { (very fit) to } 7 \\
\text { (severely frail). }\end{array}$ & $\begin{array}{l}\text { Robust: } 31.4 \% . \\
\text { Prefrail: } 46.1 \% \\
\text { Frail: } 22.4 \%\end{array}$ & $\begin{array}{l}\text { 1,3, and 6-month } \\
\text { postoperative } \\
\text { emergency } \\
\text { department visits } \\
\text { Readmissions } \\
\text { Mortality }\end{array}$ & $\begin{array}{l}\text { More cumulative events occurred for frail } \\
\text { than for robust patients for each adverse } \\
\text { outcome. Frailty had a long-term effect on } \\
\text { each adverse outcome. }\end{array}$ \\
\hline $\begin{array}{c}\text { Inoue et al., } 2019 \\
\text { [78] } \\
\text { Japan }\end{array}$ & $\begin{array}{l}\text { Retrospective } \\
\text { observational } \\
\text { study, } \\
\text { two acute } \\
\text { hospitals }\end{array}$ & $\begin{array}{l}\text { Mean 83.7 (SD 7.4) } \\
52(19.3) / 217(80.7)\end{array}$ & 274 & $\begin{array}{l}\text { Modified frailty index } \\
\text { Nineteen items } \\
\text { Comorbidities, cognitive function, } \\
\text { and walking ability }\end{array}$ & $\begin{array}{l}\text { Mean modified frailty } \\
\text { score: } 3.2 \pm 1.9 \text { points } \\
\text { (minimum to a } \\
\text { maximum range of } 0 \text { to } \\
\text { 9) }\end{array}$ & $\begin{array}{l}\text { Efficiency on the } \\
\text { motor-Functional } \\
\text { Independence } \\
\text { Measure } \\
\text { Postoperative } \\
\text { complication } \\
\text { Discharge disposition }\end{array}$ & $\begin{array}{l}\text { Higher modified frailty index was } \\
\text { significantly associated with increased } \\
\text { likelihood of lower functional recovery (OR, } \\
1.60 ; 95 \% \text { CI, } 1.32-1.93) \text {, occurrence of } \\
\text { postoperative complication (OR, } 1.32 ; 95 \% \\
\text { CI, 1.13-1.54) and not returning home (OR, } \\
1.77 ; 95 \% \text { CI, 1.38-2.26). }\end{array}$ \\
\hline $\begin{array}{l}\text { Van De Ree et al., } \\
2019 \text { [79] } \\
\text { Netherlands }\end{array}$ & $\begin{array}{c}\text { Prospective } \\
\text { observational } \\
\text { study, } \\
10 \text { participating } \\
\text { Dutch hospitals }\end{array}$ & $\begin{array}{l}\text { Mean } 80.27 \text { (SD 8.62) } \\
206(29.6) / 490(70.4)\end{array}$ & 696 & $\begin{array}{l}\text { Groningen Frailty Indicator } \\
\text { questionnaire } \\
\text { Consisted of } 15 \text { questions } \\
\text { Physical, cognitive, social, and } \\
\text { psychological impairments } \\
\text { Score on a scale of } 0-15 \\
\text { Score of } 4 \text { or higher suggests frailty }\end{array}$ & $53.3 \%$ & $\begin{array}{c}\text { EuroQol-5 } \\
\text { Dimensions ICEpop } \\
\text { CAPability measure } \\
\text { for Older people }\end{array}$ & $\begin{array}{l}\text { Frailty was negatively associated with } \\
\text { EuroQol- } 5 \text { Dimensions }(\beta-0.333 ; 95 \% \text { CI } \\
-0.366 \text { to }-0.299) \text {, self-rated health }(\beta-21.9 \text {; } \\
95 \% \text { II }-24.2 \text { to }-19.6) \text {, and capability and } \\
\text { well-being }(\beta-0.296 \text {; } 95 \% \text { CI }-0.322 \text { to } \\
-0.270) 1 \text { year after hip fracture. }\end{array}$ \\
\hline
\end{tabular}


Table 3. Cont.

\begin{tabular}{|c|c|c|c|c|c|c|c|}
\hline $\begin{array}{l}\text { Author, Year, } \\
\text { Country }\end{array}$ & $\begin{array}{l}\text { Design, } \\
\text { Setting }\end{array}$ & $\begin{array}{c}\text { Age } \\
\text { Male/Female, } n(\%)\end{array}$ & $\begin{array}{c}\text { Sample } \\
\text { Size }\end{array}$ & $\begin{array}{l}\text { Diagnosis Criteria } \\
\text { Details of Criteria }\end{array}$ & Prevalence of Frailty & Outcome & Main Results \\
\hline $\begin{array}{c}\text { Jorissen et al., } 2020 \\
\text { [80] } \\
\text { Australia }\end{array}$ & $\begin{array}{l}\text { Retrospective } \\
\text { cohort study, } \\
\text { historical national } \\
\text { cohort of the } \\
\text { Registry of Senior } \\
\text { Australians }\end{array}$ & $\begin{array}{l}\text { Mean } 85.8(\text { SD } 6.3) \\
1164(24.4) / 3607(75.6)\end{array}$ & 4771 & $\begin{array}{c}\text { Frailty index } \\
\text { Forty-four deficits } \\
\text { Eight activity limitations, } 24 \text { health } \\
\text { conditions, and three signs and } \\
\text { symptoms } \\
0-0.18 \text { (quartile } 1), 0.19-0.23 \\
\text { (quartile 2), } 0.24-0.27 \text { (quartile } 3 \text { ), } \\
\text { and } 0.28-0.41 \text { (quartile 4) }\end{array}$ & $\begin{array}{l}\text { Quartile 1: } 1307(27.4 \%) \\
\text { Quartile 2: } 1158(24.3 \%) \\
\text { Quartile 3: } 1123(23.5 \%) \\
\text { Quartile 4: } 1183(24.8 \%)\end{array}$ & $\begin{array}{l}2 \text { year survival } \\
\text { ADL limitations } \\
\text { Permanent residential } \\
\text { aged care for patients } \\
\text { living in the } \\
\text { community }\end{array}$ & $\begin{array}{l}\text { The two-year survival of patients following } \\
\text { hip fracture was } 43.7 \% \text { ( } 95 \% \text { CI } 40.9-46.7 \%) \\
\text { in those in the highest quartile of frailty, } \\
\text { compared with } 54.4 \% \text { ( } 95 \% \text { CI } 51.8-57.2 \%) \\
\text { for those in the lowest quartile (HR = } 1.25 \text {, } \\
95 \% \text { CI } 1.11-1.41) \text {. } \\
\text { No associations were found between } \\
\text { pre-fracture frailty and post fracture ADL } \\
\text { limitations. } \\
\text { No association of frailty with transition to } \\
\text { permanent residential aged care for patients } \\
\text { living in the community was observed (HR } \\
=0.98,95 \% \text { CI } 0.81-1.18) \text {. }\end{array}$ \\
\hline $\begin{array}{l}\text { Lu et al., } 2020[81] \\
\text { China }\end{array}$ & $\begin{array}{l}\text { Longitudinal and } \\
\text { observational } \\
\text { study, university } \\
\text { hospital }\end{array}$ & $\begin{array}{l}\text { Mean } 77.5 \text { (SD 8.5) } \\
43(33) / 87 \text { (67) }\end{array}$ & 130 & $\begin{array}{l}\text { The modified Krishnan FI } \\
\text { Physical health, mental health, } \\
\text { cognitive function, self-care ability, } \\
\text { life satisfaction, and social function } \\
\text { The Canadian study of health and } \\
\text { aging frailty index } \\
\text { Cognition, existing diseases, } \\
\text { self-care deficits, and abnormal } \\
\text { physical signs }\end{array}$ & $\begin{array}{c}\text { The modified Krishnan } \\
\text { FI } \\
\text { Low: } 39 \% \\
\text { Medium: } 50 \% \\
\text { High: } 12 \% \\
\text { The Canadian study of } \\
\text { health and aging frailty } \\
\text { index } \\
\text { Low: } 63 \% \\
\text { Medium: } 36 \% \\
\text { High: } 0.8 \%\end{array}$ & $\begin{array}{c}\text { Death } \\
\text { Rate of readmission to } \\
\text { the hospital } \\
\text { Fall within } 3 \text { months } \\
\text { Hip function } \\
\text { Daily activities at } \\
\text { 3 months after surgery }\end{array}$ & $\begin{array}{l}\text { The modified Krishnan FI correlated with } \\
\text { the Japanese Orthopedic Association hip } \\
\text { score (pain, activity, walking ability, and } \\
\text { ability for daily living; } R=0.249, p=0.005) \text {, } \\
\text { whereas the Canadian study of health and } \\
\text { aging frailty index was not correlated } \\
(R=0.125, p=0.170) \text {. } \\
\text { Both the modified Krishnan FI }(R=0.415, \\
p<0.001) \text { and the Canadian study of health } \\
\text { and aging frailty index }(R=0.332, p<0.001) \\
\text { were significantly correlated with the } \\
\text { functional recovery scale score. }\end{array}$ \\
\hline $\begin{array}{l}\text { Pizzonia et al., } \\
2020 \text { [82] } \\
\text { Italy }\end{array}$ & $\begin{array}{c}\text { Prospective } \\
\text { observational } \\
\text { study, } \\
\text { acute hospital } \\
\text { Prospective cohort }\end{array}$ & $\begin{array}{l}\text { Mean } 86.5(\text { SD } 5.65) \\
\quad 80(22) / 284(78)\end{array}$ & 364 & $\begin{array}{c}\text { Modified frailty index } \\
19 \text { items } \\
\text { Comorbidities, cognitive function, } \\
\text { and walking ability }\end{array}$ & $\begin{array}{l}\text { Robust: } 2.2 \% \\
\text { Prefrail: } 14.9 \% \\
\text { Frail: } 82.9 \%\end{array}$ & $\begin{array}{c}\text { Mortality } \\
\text { (median follow-up of } \\
2.4 \text { years) }\end{array}$ & $\begin{array}{l}\text { Modified frailty index was predictive of } \\
\text { long-term mortality. }\end{array}$ \\
\hline $\begin{array}{c}\text { Low et al., } 2020 \\
\quad[83] \\
\text { Australia }\end{array}$ & $\begin{array}{l}\text { study, } \\
\text { rehabilitation and } \\
\text { two geriatric } \\
\text { evaluation and } \\
\text { management } \\
\text { wards }\end{array}$ & $\begin{array}{c}\text { Median } 86 \text { years } \\
\text { (interquartile range 81-90) } \\
254(30.1) / 590(69.9)\end{array}$ & 844 & $\begin{array}{l}\text { Clinical Frailty Scale } \\
9 \text { points scale }\end{array}$ & $69.9 \%$ & $\begin{array}{c}\text { FIM efficiency } \\
\text { Mobility } \\
\text { Discharge disposition }\end{array}$ & $\begin{array}{l}\text { Clinical Frailty Scale was the strongest } \\
\text { independent predictor of poorer FIM } \\
\text { efficiency, inability to recover pre-fracture } \\
\text { mobility, and return to community dwelling. }\end{array}$ \\
\hline $\begin{array}{c}\text { Narula et al., } 2020 \\
\text { [84] } \\
\text { Australia }\end{array}$ & $\begin{array}{l}\text { Retrospective } \\
\text { observational } \\
\text { study, } \\
\text { acute hospital }\end{array}$ & $\begin{array}{c}\text { Nonfrail: } 73.8(8.8) \\
\text { Vulnerable: } 80.3(9.0) \\
\text { Mildly frail: } 84.3(8.3) \\
\text { Moderately frail: } 84.7(6.9) \\
\text { Severely frail: } 86.6(7.3) \\
135(26.5) / 374(73.5)\end{array}$ & 509 & $\begin{array}{l}\text { Clinical Frailty Scale } \\
9 \text { points scale }\end{array}$ & $\begin{array}{c}\text { Non frail: } 15.7 \% \\
\text { Vulnerable: } 17.9 \% \\
\text { Mildly frail: } 23.0 \% \\
\text { Moderately frail: } 13.8 \% \\
\text { Severely frail: } 29.7 \%\end{array}$ & $\begin{array}{l}30 \text { day and 1-year } \\
\text { mortality }\end{array}$ & $\begin{array}{l}\text { The Clinical Frailty Scale demonstrated } \\
\text { superior discriminative ability in predicting } \\
\text { mortality (area under the curve } 0.699 ; 95 \% \text { CI } \\
0.651 \text { to } 0.747 \text { ) when compared with the ASA } \\
\text { and chronological age groups. }\end{array}$ \\
\hline
\end{tabular}

Abbreviations: CI, confidence interval; FI, frailty index; IQR, interquartile range; ASA, American Society of Anesthesiologists; NHFS, Nottingham Hip Fracture Score; MNA, Mini Nutritional Assessment; ROC, receiver-operating characteristic; FIM, Functional Independence Measure; ADL, activities of daily living; OR, odds ratio; HR, hazard ratio. 
The concept of the frailty index consists of the accumulation of health-related deficits, such as signs, symptoms, disease, and disability. The frailty index is easy to use in clinical practice because it consists mainly of medical conditions [69] and can be evaluated from the medical record. Patel et al. [70], Inoue et al. [78], Vasu et al. [76], and Pizzonia M et al. [82] adopted 19 items and Krishnan et al. [71] adopted 51 items to develop the modified frailty index for hip fracture patients. These models suggest that frailty is a continuous score that considers disability, comorbidity, and symptoms. Higher scores are considered to be associated with greater frailty. They reported an association of the modified frailty index with mortality [70,76,82], occurrences of complications [78], length of hospital stay [71], discharge disposition [71,78] from acute hospital, and low functional recovery [78]. Further studies are needed to enable an easy diagnosis of frailty in clinical practice for hip fracture patients.

\subsection{Impact of Frailty on Clinical Outcomes}

Many previous studies reported that frailty was a predictor of adverse outcomes. The clinical outcomes included mortality $[70,71,74-77,82,84]$, the occurrence of complications $[72,73,78]$, length of hospital stay [72-74], ADL [78,80,81,83], QOL [79], and discharge disposition [72,74,78,83]. However, few well-designed studies were conducted. Thus, it is necessary to develop diagnostic criteria that are simple, highly accurate, able to predict adverse outcomes, and suitable for hip fracture patients.

\section{Nutritional Intervention for Patients with Hip Fracture}

Based on the current evidence, the effectiveness of nutritional therapy alone for hip fracture patients is unclear. A systematic review [6] of nutritional interventions for hip fracture patients reported only low-quality evidence to reduce complications and no clear effect on mortality. Many intervention studies examined the effect of oral administration of protein [85-92], $\beta$-hydroxy- $\beta$-methylbutyrate [93], vitamin D [94-96], whey protein [97,98], or combined calcium $\beta$-hydroxy- $\beta$-methylbutyrate (CaHMB), vitamin D, and protein intake [99] on clinical outcomes. One randomized controlled trial for hip fracture patients conducted an intervention to calculate energy requirements by measuring the resting energy expenditure using an indirect calorimeter [100]. In individual randomized controlled trials, the group that received the nutritional intervention had better outcomes than the control group in terms of occurrence of complications [87,100], severity of pressure ulcers [88], length of hospital stay [89], readmission rate [94], nutritional status [86], muscle strength [98], muscle mass [91,93], and wound-healing period [99]. Conversely, there was no significant difference in nutritional status [85,89] or mortality [87] between the group that received a nutritional intervention alone and the control group. The effects of nutritional intervention on ADL are not consistent $[87,89-91,98]$. There were no intervention studies that reported enhanced rehabilitation used in combination with nutritional therapy. These discrepancies might suggest that nutritional interventions alone are insufficient to improve clinical outcomes.

\section{Combined Nutritional Intervention with Rehabilitation Exercise}

A combination of nutrition and exercise interventions is effective for elderly patients with sarcopenia. A combination of amino acid intake and exercise improved muscle strength, muscle mass, and ADL of community-dwelling women with sarcopenia [101] and sarcopenic patients with cerebrovascular disease [102]. A meta-analysis reported that the combination of nutrition and exercise had a positive effect on physical function in community-dwelling elderly individuals [103]. Combined nutrition and exercise interventions promoted muscle protein synthesis compared with each of these interventions alone [104]. Thus, these combination interventions for hip fracture patients may contribute to improved clinical outcomes.

\section{Advanced Strategies for Improvement of Clinical Outcomes}

To improve clinical outcomes effectively, medical professionals should be aware of geriatric nutritional problems in hip fracture patients (Figure 2). On the basis of geriatric nutritional evaluation, 
we must be careful about iatrogenic sarcopenia [7]. Iatrogenic sarcopenia is caused by hospitalization and is drug-related [7]. Hospitalization-related iatrogenic sarcopenia is caused by physicians, nurses, and other medical professionals $[105,106]$. Iatrogenic sarcopenia mainly comprises inactivity- and nutritional-related factors. Inactivity-related iatrogenic sarcopenia is mainly caused by unnecessary inactivity during the perioperative period. In hospitalized hip fracture patients, approximately $99 \%$ of the day consists of sedentary time [107]. The incidence of sarcopenia in acute hospitals is approximately $15 \%$, and the duration of bed rest is associated with the incidence of sarcopenia [108]. In patients in rehabilitation hospitals, increased time away from bed is more effective in improving ADL [109]. Medical professionals should pay close attention to iatrogenic sarcopenia, and avoiding unnecessary bed rest, immobility, and deconditioning in patients could prevent activity-related sarcopenia.

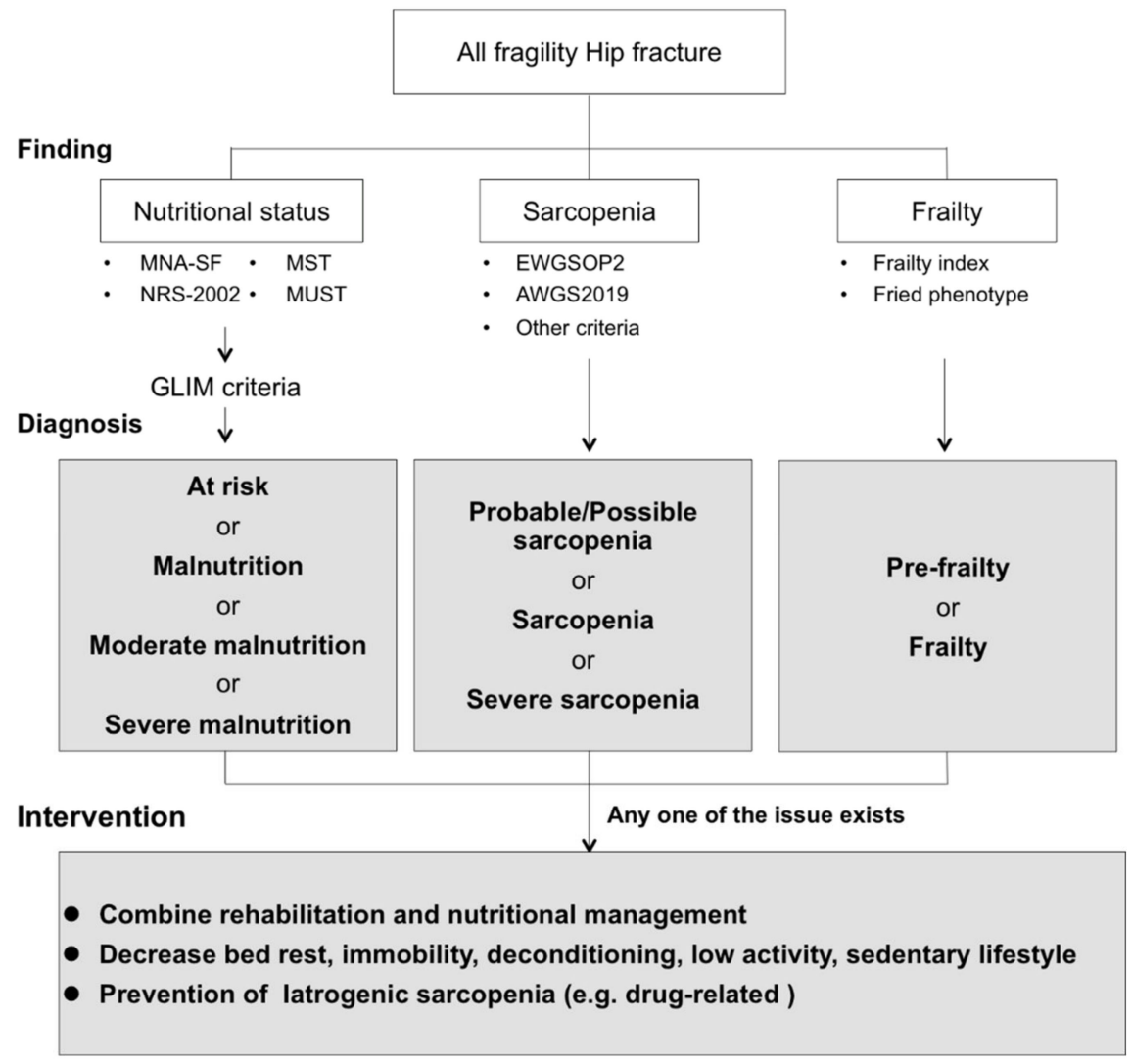

Figure 2. The specific strategies of geriatric nutritional evaluation and advanced intervention for patients with fragility hip fracture. Abbreviations: MNA-SF, Mini Nutritional Assessment-Short Form; MST, Malnutrition Screening Tool; NRS-2002, Nutrition Risk Screening 2002; MUST, Malnutrition Universal Screening Tool; EWGSOP, European Working Group on Sarcopenia in Older People; AWGS, Asian Working Group for Sarcopenia.

In hip fracture patients, nutritional-related iatrogenic sarcopenia requires a comprehensive approach. Only $17.5 \%$ of patients meet their energy requirements in the first week after hip surgery [110]. Additionally, multiple factors are associated with reduced food intake after fractures [111,112], and it is clear that interventions that merely administer supplements are insufficient for improving clinical outcomes. Bell et al. [113] reported that intensive individualized, multidisciplinary (orthopedic and geriatric physician, nursing staff, physiotherapists and occupational therapists, dietitian, pharmacist, etc.) interventions reduced barriers to food intake; food intake increased in the group with multidisciplinary intervention (mean $1489.0 \mathrm{kcal} /$ day, protein intake of $1.13 \mathrm{~g} / \mathrm{body}$ weight) compared with the group with conventional care (mean $707.4 \mathrm{kcal} / \mathrm{day}$, protein intake of $0.60 \mathrm{~g} / \mathrm{body}$ weight) in hip fracture patients. Additionally, medical professionals should pay attention to sarcopenic dysphagia accompanied by deterioration in nutritional status after hip surgery [56]. 
A multidisciplinary, comprehensive pragmatic intervention trial is required for hip fractures with overlapping undernutrition, sarcopenia, and frailty. Compared with randomized controlled trials, pragmatic trials can be routinely conducted with less stringent inclusion and exclusion criteria. Therefore, selection bias can be controlled, and the results can be easily generalized to routine clinical practice. Comprehensive multidisciplinary interventions are necessary to prevent nutritional-related iatrogenic sarcopenia in patients with hip fracture.

\section{Comprehensive Intervention Based on Combined Nutritional Intervention with Rehabilitation Exercise for Patients with Hip Fractures}

The geriatric nutritional evaluation, a comprehensive approach that combines nutritional management and rehabilitation, is a key strategy for improving clinical outcomes [105,106,114]. The concept of "rehabilitation nutrition" [114] invented in Japan may be effective for managing geriatric nutritional problems in fragility hip fracture patients. "Rehabilitation nutrition" is defined as that which (i) holistically evaluates the presence and causes of nutritional disorders, sarcopenia, and excess or deficiency of nutrient intake as per the International Classification of Functioning, Disability and Health; (ii) conducts rehabilitation nutrition diagnosis and rehabilitation nutrition goal setting; and (iii) elicits the highest body functions, activities, participations, and QOL by improving nutritional status, sarcopenia, and frailty using "nutrition care management in consideration of rehabilitation" and "rehabilitation in consideration of nutrition" in people with a disability and frail older people [114]. This rehabilitation nutrition concept can maximize functional recovery and QOL through the diagnosis and intervention of undernutrition, sarcopenia, and frailty. Previous studies reported the usefulness of this comprehensive approach, which combines nutritional management and rehabilitation [102,115]. Future research on comprehensive interventions combined with nutrition and rehabilitation, specifically for hip fracture patients, is strongly needed.

\section{Strengths and Limitations}

The strength of this review is that we summarized recent research that focused on the nutritional problem of elderly patients with hip fracture and mentioned new intervention strategies for geriatric nutritional problems. However, this review also has methodological limitations. For example, we did not use a strict literature search for a systematic review, which is necessary to further explore the impact of sarcopenia and frailty on the clinical outcomes of hip fractures.

\section{Conclusions}

The overlap between undernutrition, sarcopenia, and frailty is a characteristic of fragility hip fracture patients. Geriatric nutritional problems have a strong impact on adverse outcomes after hip fracture. To improve clinical outcomes effectively, medical professionals should be aware of geriatric nutritional problems in hip fracture patients. A comprehensive approach that combines nutritional management and rehabilitation is a key strategy for improving clinical outcomes. New, comprehensive, advanced, and hip-fracture-specific intervention strategies are strongly needed.

Supplementary Materials: The following are available online at http://www.mdpi.com/2072-6643/12/12/3743/s1: Supplementary Table S1: Results of the quality assessment of the study on undernutrition and clinical outcomes; Supplementary Table S2: Results of the quality assessment of the study on sarcopenia and clinical outcomes; Supplementary Table S3: Results of the quality assessment of the study on frailty and clinical outcomes; Supplementary Figure S1: Flow diagrams of electronic search strategy for undernutrition with hip fractures; Supplementary Figure S2: Flow diagrams of electronic search strategy for sarcopenia with hip fractures; Supplementary Figure S3: Flow diagrams of electronic search strategy for frailty with hip fractures.

Author Contributions: Conceptualization, T.I., K.M. (Keisuke Maeda), A.N., A.S., J.U., K.M. (Kenta Murotani), K.S., and A.T.; methodology, T.I. and K.M. (Keisuke Maeda); writing—original draft preparation, T.I. and K.M. (Keisuke Maeda); writing-review and editing, T.I., K.M. (Keisuke Maeda), A.N., A.S., J.U., K.M. (Kenta Murotani), K.S., and A.T.; supervision, K.M. (Keisuke Maeda) and A.T.; funding acquisition, K.M. (Keisuke Maeda). All authors have read and agreed to the published version of the manuscript. 
Funding: This research was funded by the Research Funding of Longevity Sciences (grant 20-57 to K. Maeda).

Acknowledgments: We give special thanks to all of the individuals involved in this review who greatly facilitated this work.

Conflicts of Interest: The authors declare no conflict of interest.

\section{References}

1. Johnell, O.; Kanis, J.A. An estimate of the worldwide prevalence, mortality and disability associated with hip fracture. Osteoporos. Int. 2004, 15, 897-902. [CrossRef]

2. Cooper, C.; Campion, G.; Melton, L.J. Hip fractures in the elderly: A world-wide projection. Osteoporos. Int. 1992, 2, 285-289. [CrossRef]

3. Johnell, O.; Kanis, J. Epidemiology of osteoporotic fractures. Osteoporos. Int. 2005, 16, 6-10. [CrossRef]

4. Shyu, Y.-I.L.; Chen, M.-C.; Liang, J.; Wu, C.-C.; Su, J.-Y. Predictors of functional recovery for hip fractured elders during 12 months following hospital discharge: A prospective study on a Taiwanese sample. Osteoporos. Int. 2004, 15, 475-482. [CrossRef]

5. Braithwaite, R.S.; Col, N.F.; Wong, J.B. Estimating hip fracture morbidity, mortality and costs. J. Am. Geriatr. Soc. 2003, 51, 364-370. [CrossRef] [PubMed]

6. Avenell, A.; Handoll, H. Nutritional supplementation for hip fracture aftercare in the elderly. Cochrane Database Syst. Rev. 2016. [CrossRef] [PubMed]

7. Cruz-Jentoft, A.J.; Sayer, A.A. Sarcopenia. Lancet 2019, 393, 2636-2646. [CrossRef]

8. Liberati, A.; Altman, D.G.; Tetzlaff, J.; Mulrow, C.; Gøtzsche, P.C.; Ioannidis, J.P.A.; Clarke, M.; Devereaux, P.J.; Kleijnen, J.; Moher, D. The PRISMA statement for reporting systematic reviews and meta-analyses of studies that evaluate health care interventions: Explanation and elaboration. PLoS Med. 2009, 6. [CrossRef] [PubMed]

9. Cruz-Jentoft, A.J.; Baeyens, J.P.; Bauer, J.M.; Boirie, Y.; Cederholm, T.; Landi, F.; Martin, F.C.; Michel, J.P.; Rolland, Y.; Schneider, S.M.; et al. Sarcopenia: European consensus on definition and diagnosis. Age Ageing 2010, 39, 412-423. [CrossRef]

10. National Heart Lung and Blood Institute. Study Quality Assessment Tools. Available online: https: //www.nhlbi.nih.gov/health-topics/study-quality-assessment-tools (accessed on 17 November 2020).

11. Nishioka, S.; Wakabayashi, H.; Momosaki, R. Nutritional Status Changes and Activities of Daily Living after Hip Fracture in Convalescent Rehabilitation Units: A Retrospective Observational Cohort Study from the Japan Rehabilitation Nutrition Database. J. Acad. Nutr. Diet. 2018, 118, 1270-1276. [CrossRef]

12. Helminen, H.; Luukkaala, T.; Saarnio, J.; Nuotio, M. Comparison of the Mini-Nutritional Assessment short and long form and serum albumin as prognostic indicators of hip fracture outcomes. Injury 2017, 48, 903-908. [CrossRef] [PubMed]

13. Koren-Hakim, T.; Weiss, A.; Hershkovitz, A.; Otzrateni, I.; Grosman, B.; Frishman, S.; Salai, M.; Beloosesky, Y. The relationship between nutritional status of hip fracture operated elderly patients and their functioning, comorbidity and outcome. Clin. Nutr. 2012, 31, 917-921. [CrossRef] [PubMed]

14. Mazzola, P.; Ward, L.; Zazzetta, S.; Broggini, V.; Anzuini, A.; Valcarcel, B.; Brathwaite, J.S.; Pasinetti, G.M.; Bellelli, G.; Annoni, G. Association Between Preoperative Malnutrition and Postoperative Delirium after Hip Fracture Surgery in Older Adults. J. Am. Geriatr. Soc. 2017, 65, 1222-1228. [CrossRef] [PubMed]

15. Inoue, T.; Misu, S.; Tanaka, T.; Sakamoto, H.; Iwata, K.; Chuman, Y.; Ono, R. Pre-fracture nutritional status is predictive of functional status at discharge during the acute phase with hip fracture patients: A multicenter prospective cohort study. Clin. Nutr. 2017, 36, 6-11. [CrossRef]

16. Bajada, S.; Smith, A.; Morgan, D. Pre-operative nutritional serum parameters as predictors of failure after internal fixation in undisplaced intracapsular proximal femur fractures. Injury 2015, 46, 1571-1576. [CrossRef]

17. Goisser, S.; Schrader, E.; Singler, K.; Bertsch, T.; Gefeller, O.; Biber, R.; Bail, H.J.; Sieber, C.C.; Volkert, D. Malnutrition According to Mini Nutritional Assessment Is Associated with Severe Functional Impairment in Geriatric Patients before and up to 6 Months after Hip Fracture. J. Am. Med. Dir. Assoc. 2015, 1-7. [CrossRef]

18. Van Wissen, J.; van Stijn, M.F.M.; Doodeman, H.J.; Houdijk, A.P.J. Mini nutritional assessment and mortality after hip fracture surgery in the elderly. J. Nutr. Health Aging 2016, 20, 964-968. [CrossRef] 
19. Zanetti, M.; Gortan Cappellari, G.; Ratti, C.; Ceschia, G.; Murena, L.; De Colle, P.; Barazzoni, R. Poor nutritional status but not cognitive or functional impairment per se independently predict 1 year mortality in elderly patients with hip-fracture. Clin. Nutr. 2019, 38, 1607-1612. [CrossRef]

20. Milte, R.; Miller, M. Dietetic care of hip fracture patients across Australia: Are we doing enough? Nutr. Diet. 2011, 68, 214-220. [CrossRef]

21. Yagi, T.; Oshita, Y.; Okano, I.; Kuroda, T.; Ishikawa, K.; Nagai, T.; Inagaki, K. Controlling nutritional status score predicts postoperative complications after hip fracture surgery. BMC Geriatr. 2020, 20, 1-7. [CrossRef]

22. Kotera, A. Geriatric Nutritional Risk Index and Controlling Nutritional Status Score can predict postoperative 180-day mortality in hip fracture surgeries. JA Clin. Rep. 2019, 5. [CrossRef] [PubMed]

23. Hao, L.; Carson, J.L.; Schlussel, Y.; Noveck, H.; Shapses, S.A. Vitamin D deficiency is associated with reduced mobility after hip fracture surgery: A prospective study. Am. J. Clin. Nutr. 2020, 112, 613-618. [CrossRef] [PubMed]

24. Han, T.S.; Yeong, K.; Lisk, R.; Fluck, D.; Fry, C.H. Prevalence and consequences of malnutrition and malnourishment in older individuals admitted to hospital with a hip fracture. Eur. J. Clin. Nutr. 2020. [CrossRef] [PubMed]

25. Vosoughi, A.R.; Emami, M.J.; Pourabbas, B.; Mahdaviazad, H. Factors increasing mortality of the elderly following hip fracture surgery: Role of body mass index, age, and smoking. Musculoskelet. Surg. 2017, 101, 25-29. [CrossRef] [PubMed]

26. Miyanishi, K.; Jingushi, S.; Torisu, T. Mortality after hip fracture in Japan: The role of nutritional status. J. Orthop. Surg. (Hong Kong) 2010, 18, 265-270. [CrossRef]

27. Stone, A.V.; Jinnah, A.; Wells, B.J.; Atkinson, H.; Miller, A.N.; Futrell, W.M.; Lenoir, K.; Emory, C.L. Nutritional markers may identify patients with greater risk of re-admission after geriatric hip fractures. Int. Orthop. 2018, 42, 231-238. [CrossRef] [PubMed]

28. Gumieiro, D.N.; Rafacho, B.P.M.; Gonçalves, A.F.; Tanni, S.E.; Azevedo, P.S.; Sakane, D.T.; Carneiro, C.A.S.; Gaspardo, D.; Zornoff, L.A.M.; Pereira, G.J.C.; et al. Mini Nutritional Assessment predicts gait status and mortality 6 months after hip fracture. Br. J. Nutr. 2012, 1-5. [CrossRef]

29. Drevet, S.; Bioteau, C.; Mazière, S.; Couturier, P.; Merloz, P.; Tonetti, J.; Gavazzi, G. Prevalence of protein-energy malnutrition in hospital patients over 75 years of age admitted for hip fracture. Orthop. Traumatol. Surg. Res. 2014, 100, 669-674. [CrossRef]

30. Miu, K.Y.D.; Lam, P.S. Effects of nutritional status on 6-month outcome of hip fractures in elderly patients. Ann. Rehabil. Med. 2017, 41, 1005-1012. [CrossRef]

31. Kondrup, J.; Allison, S.P.; Elia, M.; Vellas, B.; Plauth, M. ESPEN guidelines for nutrition screening 2002. Clin. Nutr. 2003, 22, 415-421. [CrossRef]

32. Inoue, T.; Misu, S.; Tanaka, T.; Kakehi, T.; Ono, R. Acute phase nutritional screening tool associated with functional outcomes of hip fracture patients: A longitudinal study to compare MNA-SF, MUST, NRS-2002 and GNRI. Clin. Nutr. 2019, 38, 220-226. [CrossRef] [PubMed]

33. Koren-Hakim, T.; Weiss, A.; Hershkovitz, A.; Otzrateni, I.; Anbar, R.; Gross Nevo, R.F.; Schlesinger, A.; Frishman, S.; Salai, M.; Beloosesky, Y. Comparing the adequacy of the MNA-SF, NRS-2002 and MUST nutritional tools in assessing malnutrition in hip fracture operated elderly patients. Clin. Nutr. 2015, 3-8. [CrossRef]

34. Guigoz, Y. The Mini Nutritional Assessment (MNA) review of the literature-What does it tell us? J. Nutr. Health Aging 2006, 10, 466-485, discussion 485-487. [PubMed]

35. Cao, L.; Morley, J.E. Sarcopenia Is Recognized as an Independent Condition by an International Classification of Disease, Tenth Revision, Clinical Modification (ICD-10-CM) Code. J. Am. Med. Dir. Assoc. 2016, 17, 675-677. [CrossRef] [PubMed]

36. Anker, S.D.; Morley, J.E.; von Haehling, S. Welcome to the ICD-10 code for sarcopenia. J. Cachexia Sarcopenia Muscle 2016, 7, 512-514. [CrossRef] [PubMed]

37. Cruz-Jentoft, A.J.; Bahat, G.; Bauer, J.; Boirie, Y.; Bruyère, O.; Cederholm, T.; Cooper, C.; Landi, F.; Rolland, Y.; Sayer, A.A.; et al. Sarcopenia: Revised European consensus on definition and diagnosis. Age Ageing 2019, 48, 16-31. [CrossRef]

38. Edwards, M.H.; Dennison, E.M.; Aihie Sayer, A.; Fielding, R.; Cooper, C. Osteoporosis and sarcopenia in older age. Bone 2015, 80, 126-130. [CrossRef] 
39. Yamada, M.; Nishiguchi, S.; Fukutani, N.; Tanigawa, T.; Yukutake, T.; Kayama, H.; Aoyama, T.; Arai, H. Prevalence of sarcopenia in community-dwelling Japanese older adults. J. Am. Med. Dir. Assoc. 2013, 14, 911-915. [CrossRef]

40. Chen, L.K.; Liu, L.K.; Woo, J.; Assantachai, P.; Auyeung, T.W.; Bahyah, K.S.; Chou, M.Y.; Chen, L.Y.; Hsu, P.S.; Krairit, O.; et al. Sarcopenia in Asia: Consensus report of the Asian working group for sarcopenia. J. Am. Med. Dir. Assoc. 2014, 15, 95-101. [CrossRef]

41. Chen, L.; Woo, J.; Assantachai, P.; Auyeung, T.; Chou, M.; Iijima, K.; Jang, H.C.; Kang, L.; Kim, M.; Kim, S.; et al. Asian Working Group for Sarcopenia: 2019 Consensus Update on Sarcopenia Diagnosis and Treatment. J. Am. Med. Dir. Assoc. 2020, 21, 200-307.e2. [CrossRef]

42. Studenski, S.A.; Peters, K.W.; Alley, D.E.; Cawthon, P.M.; McLean, R.R.; Harris, T.B.; Ferrucci, L.; Guralnik, J.M.; Fragala, M.S.; Kenny, A.M.; et al. The FNIH sarcopenia project: Rationale, study description, conference recommendations, and final estimates. J. Gerontol. Ser. A Biol. Sci. Med. Sci. 2014, 69, 547-558. [CrossRef] [PubMed]

43. Landi, F.; Calvani, R.; Ortolani, E.; Salini, S.; Martone, A.M.; Santoro, L.; Santoliquido, A.; Sisto, A.; Picca, A.; Marzetti, E. The association between sarcopenia and functional outcomes among older patients with hip fracture undergoing in-hospital rehabilitation. Osteoporos. Int. 2017, 28, 1569-1576. [CrossRef] [PubMed]

44. Malmstrom, T.K.; Morley, J.E. SARC-F: A simple questionnaire to rapidly diagnose sarcopenia. J. Am. Med. Dir. Assoc. 2013, 14, 531-532. [CrossRef] [PubMed]

45. González-Montalvo, J.I.; Alarcón, T.; Gotor, P.; Queipo, R.; Velasco, R.; Hoyos, R.; Pardo, A.; Otero, A. Prevalence of sarcopenia in acute hip fracture patients and its influence on short-term clinical outcome. Geriatr. Gerontol. Int. 2015. [CrossRef] [PubMed]

46. Di Monaco, M.; Castiglioni, C.; De Toma, E.; Gardin, L.; Giordano, S.; Di Monaco, R.; Tappero, R. Presarcopenia and sarcopenia in hip-fracture women: Prevalence and association with ability to function in activities of daily living. Aging Clin. Exp. Res. 2015, 27, 465-472. [CrossRef] [PubMed]

47. Chang, C.D.; Wu, J.S.; Mhuircheartaigh, J.N.; Hochman, M.G.; Rodriguez, E.K.; Appleton, P.T.; Mcmahon, C.J. Effect of sarcopenia on clinical and surgical outcome in elderly patients with proximal femur fractures. Skelet. Radiol. 2018, 47, 771-777. [CrossRef] [PubMed]

48. Kim, Y.K.; Yi, S.R.; Lee, Y.H.; Kwon, J.; Jang, S.I.; Park, S.H. Effect of Sarcopenia on Postoperative Mortality in Osteoporotic Hip Fracture Patients. J. Bone Metab. 2018, 25, 227. [CrossRef]

49. Yoo, J.I.; Kim, H.; Ha, Y.C.; Kwon, H.B.; Koo, K.H. Osteosarcopenia in patients with hip fracture is related with high mortality. J. Korean Med. Sci. 2018, 33, 1-9. [CrossRef]

50. Steihaug, O.M.; Gjesdal, C.G.; Bogen, B.; Kristoffersen, M.H.; Lien, G.; Hufthammer, K.O.; Ranhoff, A.H. Does sarcopenia predict change in mobility after hip fracture? A multicenter observational study with one-year follow-up. BMC Geriatr. 2018, 18, 1-10. [CrossRef]

51. Malafarina, V.; Malafarina, C.; Ugarte, A.B.; Martinez, J.A.; Goñi, I.A.; Zulet, M.A. Factors associated with sarcopenia and 7-year mortality in very old patients with hip fracture admitted to rehabilitation units: A pragmatic study. Nutrients 2019, 11, 2243. [CrossRef]

52. Byun, S.E.; Kim, S.; Kim, K.H.; Ha, Y.C. Psoas cross-sectional area as a predictor of mortality and a diagnostic tool for sarcopenia in hip fracture patients. J. Bone Miner. Metab. 2019, 37, 871-879. [CrossRef] [PubMed]

53. Chen, Y.P.; Wong, P.K.; Tsai, M.J.; Chang, W.C.; Hsieh, T.S.; Leu, T.H.; Jeff Lin, C.F.; Lee, C.H.; Kuo, Y.J.; Lin, C.Y. The high prevalence of sarcopenia and its associated outcomes following hip surgery in Taiwanese geriatric patients with a hip fracture. J. Formos. Med. Assoc. 2020. [CrossRef] [PubMed]

54. Chiles Shaffer, N.; Huang, Y.; Abraham, D.S.; Cheng, Y.J.; Lu, W.; Gruber-Baldini, A.L.; Hochberg, M.C.; Guralnik, J.; Magaziner, J.; Orwig, D. Comparing Longitudinal Sarcopenia Trends by Definitions Across Men and Women After Hip Fracture. J. Am. Geriatr. Soc. 2020, 1-8. [CrossRef] [PubMed]

55. Shin, W.C.; Jang, J.H.; Seo, H.E.; Suh, K.T.; Moon, N.H. Prevalence and clinical impact of sarcopenia in osteoporotic hip fracture: Single center retrospective cohort study. Acta Orthop. Traumatol. Turc. 2020, 54, 27-33. [CrossRef] [PubMed]

56. Nagano, A.; Maeda, K.; Shimizu, A.; Nagami, S.; Takigawa, N.; Ueshima, J.; Suenaga, M. Association of sarcopenic dysphagia with underlying sarcopenia following hip fracture surgery in older women. Nutrients 2020, 12, 1365. [CrossRef]

57. Ha, Y.C.; Won, C.W.; Kim, M.; Chun, K.J.; Yoo, J.-I. SARC-F as a Useful Tool for Screening Sarcopenia in Elderly Patients with Hip Fractures. J. Nutr. Health Aging 2020, 24, 78-82. [CrossRef] 
58. Steihaug, O.M.; Gjesdal, C.G.; Bogen, B.; Kristoffersen, M.H.; Lien, G.; Ranhoff, A.H. Sarcopenia in patients with hip fracture: A multicenter cross-sectional study. PLOS ONE 2017, 12, 1-13. [CrossRef]

59. Ho, A.W.H.; Lee, M.M.L.; Chan, E.W.C.; Ng, H.M.Y.; Lee, C.W.; Ng, W.S.; Wong, S.H. Prevalence of pre-sarcopenia and sarcopenia in Hong Kong Chinese geriatric patients with hip fracture and its correlation with different factors. Hong Kong Med. J. 2015, 22, 8-10. [CrossRef]

60. Marzetti, E.; Calvani, R.; Lorenzi, M.; Marini, F.; D'Angelo, E.; Martone, A.M.; Celi, M.; Tosato, M.; Bernabei, R.; Landi, F. Serum levels of C-terminal agrin fragment (CAF) are associated with sarcopenia in older hip fractured patients. Exp. Gerontol. 2014, 60, 79-82. [CrossRef]

61. Yoo, J.I.; Ha, Y.C.; Choi, H.; Kim, K.H.; Lee, Y.K.; Koo, K.H.; Park, K.S. Malnutrition and chronic inflammation as risk factors for sarcopenia in elderly patients with hip fracture. Asia Pac. J. Clin. Nutr. 2018, 27, 527-532. [CrossRef]

62. Sánchez-Castellano, C.; Martín-Aragón, S.; Bermejo-Bescós, P.; Vaquero-Pinto, N.; Miret-Corchado, C.; Merello de Miguel, A.; Cruz-Jentoft, A.J. Biomarkers of sarcopenia in very old patients with hip fracture. J. Cachexia Sarcopenia Muscle 2020, 11, 478-486. [CrossRef] [PubMed]

63. Marzetti, E.; Calvani, R.; Lorenzi, M.; Tanganelli, F.; Picca, A.; Bossola, M.; Menghi, A.; Bernabei, R.; Landi, F. Association between myocyte quality control signaling and sarcopenia in old hip-fractured patients: Results from the Sarcopenia in HIp FracTure (SHIFT) exploratory study. Exp. Gerontol. 2016, 80, 1-5. [CrossRef] [PubMed]

64. Morley, J.E.; Vellas, B.; Abellan van Kan, G.; Anker, S.D.; Bauer, J.M.; Bernabei, R.; Cesari, M.; Chumlea, W.C.; Doehner, W.; Evans, J.; et al. Frailty consensus: A call to action. J. Am. Med. Dir. Assoc. 2013, 14, 392-397. [CrossRef] [PubMed]

65. Dent, E.; Martin, F.C.; Bergman, H.; Woo, J.; Romero-Ortuno, R.; Walston, J.D. Management of frailty: Opportunities, challenges, and future directions. Lancet 2019, 394, 1376-1386. [CrossRef]

66. Lin, H.-S.; Watts, J.N.; Peel, N.M.; Hubbard, R.E. Frailty and post-operative outcomes in older surgical patients: A systematic review. BMC Geriatr. 2016, 16, 157. [CrossRef]

67. Rolland, Y.; Abellan Van Kan, G.; Benetos, A.; Blain, H.; Bonnefoy, M.; Chassagne, P.; Jeandel, C.; Laroche, M.; Nourhashemi, F.; Orcel, P.; et al. Frailty, osteoporosis and hip fracture: Causes, consequences and therapeutic perspectives. J. Nutr. Health Aging 2008, 12, 335-346. [CrossRef]

68. Fried, L.P.; Tangen, C.M.; Walston, J.; Newman, A.B.; Hirsch, C.; Gottdiener, J.; Seeman, T.; Tracy, R.; Kop, W.J.; Burke, G.; et al. Frailty in Older Adults: Evidence for a Phenotype. J. Gerontol. Med. Sci. 2001, 56, 46-56. [CrossRef]

69. Rockwood, K.; Mcdowell, I.; Song, X.; Macknight, C.; Bergman, H.; Hogan, D.B.; Hogan, D.; Mcdowell, I.; Mitnitski, A. A global clinical measure of fitness and frailty in elderly people. Can. Med. Assoc. J. 2005, 30, 489-495. [CrossRef]

70. Patel, K.V.; Brennan, K.L.; Brennan, M.L.; Jupiter, D.C.; Shar, A.; Davis, M.L. Association of a modified frailty index with mortality after femoral neck fracture in patients aged 60 years and older. Clin. Orthop. Relat. Res. 2014, 472, 1010-1017. [CrossRef]

71. Krishnan, M.; Beck, S.; Havelock, W.; Eeles, E.; Hubbard, R.E.; Johansen, A. Predicting outcome after hip fracture: Using a frailty index to integrate comprehensive geriatric assessment results. Age Ageing 2014, 43, 122-126. [CrossRef]

72. Kistler, E.A.; Nicholas, J.A.; Kates, S.L.; Friedman, S.M. Frailty and Short-Term Outcomes in Patients with Hip Fracture. Geriatr. Orthop. Surg. Rehabil. 2015, 6, 209-214. [CrossRef] [PubMed]

73. Gleason, L.J.; Benton, E.A.; Alvarez-Nebreda, M.L.; Weaver, M.J.; Harris, M.B.; Javedan, H. FRAIL Questionnaire Screening Tool and Short-Term Outcomes in Geriatric Fracture Patients. J. Am. Med. Dir. Assoc. 2017, 18, 1082-1086. [CrossRef] [PubMed]

74. Choi, J.Y.; Cho, K.J.; Kim, S.W.; Yoon, S.J.; Kang, M.G.; Kim, K.I.; Lee, Y.K.; Koo, K.H.; Kim, C.H. Prediction of Mortality and Postoperative Complications using the Hip-Multidimensional Frailty Score in Elderly Patients with Hip Fracture. Sci. Rep. 2017, 7, 1-8. [CrossRef]

75. Winters, A.M.; Hartog, L.C.; Roijen, H.I.F.; Brohet, R.M.; Kamper, A.M. Relationship between clinical outcomes and Dutch frailty score among elderly patients who underwent surgery for hip fracture. Clin. Interv. Aging 2018, 13, 2481-2486. [CrossRef] [PubMed]

76. Vasu, B.K.; Ramamurthi, K.P.; Rajan, S.; George, M. Geriatric Patients with Hip Fracture: Frailty and Other Risk Factors Affecting the Outcome. Anesth. Essays Res. 2018, 12, 546-551. [CrossRef] [PubMed] 
77. Chen, C.L.; Chen, C.M.; Wang, C.Y.; Ko, P.W.; Chen, C.H.; Hsieh, C.P.; Chiu, H.C. Frailty is Associated with an Increased Risk of Major Adverse Outcomes in Elderly Patients Following Surgical Treatment of Hip Fracture. Sci. Rep. 2019, 9, 1-9. [CrossRef] [PubMed]

78. Inoue, T.; Misu, S.; Tanaka, T.; Kakehi, T.; Kakiuchi, M.; Chuman, Y.; Ono, R. Frailty defined by 19 items as a predictor of short-term functional recovery in patients with hip fracture. Injury 2019, 50, 2272-2276. [CrossRef] [PubMed]

79. Van De Ree, C.L.P.; Landers, M.J.F.; Kruithof, N.; De Munter, L.; Slaets, J.P.J.; Gosens, T.; Jongh, M.A.C. Effect of frailty on quality of life in elderly patients after hip fracture: A longitudinal study. BMJ Open 2019, 9, 1-8. [CrossRef]

80. Jorissen, R.N.; Lang, C.; Visvanathan, R.; Crotty, M.; Inacio, M.C. The effect of frailty on outcomes of surgically treated hip fractures in older people. Bone 2020, 136, 115327. [CrossRef]

81. Lu, W.; Dai, L.; Wu, G.; Hu, R. Comparison of two frailty indexes in hip fractures. J. Orthop. Surg. 2020, 28, 1-8. [CrossRef]

82. Pizzonia, M.; Giannotti, C.; Carmisciano, L.; Signori, A.; Rosa, G.; Santolini, F.; Caffa, I.; Montecucco, F.; Nencioni, A.; Monacelli, F. Frailty assessment, hip fracture, and long-term clinical outcomes in older adults. Eur. J. Clin. Investig. 2020, e13445. [CrossRef] [PubMed]

83. Low, S.; Wee, E.; Dorevitch, M. Impact of place of residence, frailty and other factors on rehabilitation outcomes post hip fracture. Age Ageing 2020, 1-8. [CrossRef] [PubMed]

84. Narula, S.; Lawless, A.; D’Alessandro, P.; Jones, C.W.; Yates, P.; Seymour, H. Clinical Frailty Scale is a good predictor of mortality after proximal femur fracture. Bone Jt. Open 2020, 1, 443-449. [CrossRef] [PubMed]

85. Botella-Carretero, J.I.; Iglesias, B.; Balsa, J.A.; Zamarrón, I.; Arrieta, F.; Vázquez, C. Effects of oral nutritional supplements in normally nourished or mildly undernourished geriatric patients after surgery for hip fracture: A randomized clinical trial. JPEN J. Parenter. Enter. Nutr. 2008, 32, 120-128. [CrossRef] [PubMed]

86. Botella-Carretero, J.I.; Iglesias, B.; Balsa, J.A.; Arrieta, F.; Zamarrón, I.; Vázquez, C. Perioperative oral nutritional supplements in normally or mildly undernourished geriatric patients submitted to surgery for hip fracture: A randomized clinical trial. Clin. Nutr. 2010, 29, 574-579. [CrossRef]

87. Espaulella, J.; Guyer, H.; Diaz-Escriu, F.; Mellado-Navas, J.A.; Castells, M.; Pladevall, M. Nutritional supplementation of elderly hip fracture patients. A randomized, double-blind, placebo-controlled trial. Age Ageing 2000, 29, 425-431. [CrossRef]

88. Houwing, R.H.; Rozendaal, M.; Wouters-Wesseling, W.; Beulens, J.W.J.; Buskens, E.; Haalboom, J.R. A randomised, double-blind assessment of the effect of nutritional supplementation on the prevention of pressure ulcers in hip-fracture patients. Clin. Nutr. 2003, 22, 401-405. [CrossRef]

89. Myint, M.W.W.; Wu, J.; Wong, E.; Chan, S.P.; To, T.S.J.; Chau, M.W.R.; Ting, K.H.; Fung, P.M.; Au, K.S.D. Clinical benefits of oral nutritional supplementation for elderly hip fracture patients: A single blind randomised controlled trial. Age Ageing 2013, 42,39-45. [CrossRef]

90. Neumann, M.; Friedmann, J.; Roy, M.A.; Jensen, G.L. Provision of high-protein supplement for patients recovering from hip fracture. Nutrition 2004, 20,415-419. [CrossRef]

91. Tidermark, J.; Ponzer, S.; Carlsson, P.; Söderqvist, A.; Brismar, K.; Tengstrand, B.; Cederholm, T. Effects of protein-rich supplementation and nandrolone in lean elderly women with femoral neck fractures. Clin. Nutr. 2004, 23, 587-596. [CrossRef]

92. Wyers, C.E.; Reijven, P.L.M.; Breedveld-Peters, J.J.L.; Denissen, K.F.M.; Schotanus, M.G.M.; Van Dongen, M.C.J.M.; Eussen, S.J.P.M.; Heyligers, I.C.; Van Den Brandt, P.A.; Willems, P.C.; et al. Efficacy of Nutritional Intervention in Elderly after Hip Fracture: A Multicenter Randomized Controlled Trial. J. Gerontol. Ser. A Biol. Sci. Med. Sci. 2018, 73, 1429-1437. [CrossRef] [PubMed]

93. Malafarina, V.; Uriz-Otano, F.; Malafarina, C.; Martinez, J.A.; Zulet, M.A. Effectiveness of nutritional supplementation on sarcopenia and recovery in hip fracture patients. A multi-centre randomized trial. Maturitas 2017, 101, 42-50. [CrossRef] [PubMed]

94. Bischoff-Ferrari, H.A.; Dawson-Hughes, B.; Platz, A.; Orav, E.J.; Stähelin, H.B.; Willett, W.C.; Can, U.; Egli, A.; Mueller, N.J.; Looser, S.; et al. Effect of High-Dosage Cholecalciferol and Extended Physiotherapy on Complications After Hip Fracture. Arch. Intern. Med. 2010, 170, 813-820. [CrossRef] [PubMed] 
95. Papaioannou, A.; Kennedy, C.C.; Giangregorio, L.; Ioannidis, G.; Pritchard, J.; Hanley, D.A.; Farrauto, L.; Debeer, J.; Adachi, J.D. A randomized controlled trial of vitamin D dosing strategies after acute hip fracture: No advantage of loading doses over daily supplementation. BMC Musculoskelet. Disord. 2011, 12. [CrossRef] [PubMed]

96. Bachrach-Lindström, M.; Unosson, M.; Ek, A.C.; Arnqvist, H.J. Assessment of nutritional status using biochemical and anthropometric variables in a nutritional intervention study of women with hip fracture. Clin. Nutr. 2001, 20, 217-223. [CrossRef]

97. Chevalley, T.; Hoffmeyer, P.; Bonjour, J.P.; Rizzoli, R. Early serum IGF-I response to oral protein supplements in elderly women with a recent hip fracture. Clin. Nutr. 2010, 29, 78-83. [CrossRef]

98. Niitsu, M.; Ichinose, D.; Hirooka, T.; Mitsutomi, K.; Morimoto, Y.; Sarukawa, J.; Nishikino, S.; Yamauchi, K.; Yamazaki, K. Effects of combination of whey protein intake and rehabilitation on muscle strength and daily movements in patients with hip fracture in the early postoperative period. Clin. Nutr. 2016, 35, 943-949. [CrossRef]

99. Ekinci, O.; Yanlk, S.; Terzioğlu Bebitoğlu, B.; Yllmaz Akyüz, E.; Dokuyucu, A.; Erdem, Ş. Effect of Calcium $\beta$-Hydroxy- $\beta$-Methylbutyrate (CaHMB), Vitamin D, and Protein Supplementation on Postoperative Immobilization in Malnourished Older Adult Patients with Hip Fracture. Nutr. Clin. Pract. 2016, 31, 829-835. [CrossRef]

100. Anbar, R.; Beloosesky, Y.; Cohen, J.; Madar, Z.; Weiss, A.; Theilla, M.; Koren Hakim, T.; Frishman, S.; Singer, P. Tight Calorie Control in geriatric patients following hip fracture decreases complications: A randomized, controlled study. Clin. Nutr. 2014, 33, 23-28. [CrossRef]

101. Kim, H.K.; Suzuki, T.; Saito, K.; Yoshida, H.; Kobayashi, H.; Kato, H.; Katayama, M. Effects of exercise and amino acid supplementation on body composition and physical function in community-dwelling elderly Japanese sarcopenic women: A randomized controlled trial. J. Am. Geriatr. Soc. 2012, 60, 16-23. [CrossRef]

102. Yoshimura, Y.; Bise, T.; Shimazu, S.; Tanoue, M.; Tomioka, Y.; Araki, P.T.; Nishino, P.T.; Kuzuhara, P.T.; Tomioka, P.T. Effects of a leucine-enriched amino acid supplement on muscle mass, muscle strength, and physical function in post-stroke patients with sarcopenia: A randomized controlled trial. Nutrition 2019, 58, 1-6. [CrossRef] [PubMed]

103. Yoshimura, Y.; Wakabayashi, H.; Yamada, M.; Kim, H.; Harada, A.; Arai, H. Interventions for Treating Sarcopenia: A Systematic Review and Meta-Analysis of Randomized Controlled Studies. J. Am. Med. Dir. Assoc. 2017, 18, 553.e1-553.e16. [CrossRef] [PubMed]

104. Drummond, M.J.; Dreyer, H.C.; Fry, C.S.; Glynn, E.L.; Rasmussen, B.B. Nutritional and contractile regulation of human skeletal muscle protein synthesis and mTORC1 signaling. J. Appl. Physiol. 2009, 106, 1374-1384. [CrossRef] [PubMed]

105. Wakabayashi, H. Rehabilitation nutrition in general and family medicine. J. Gen. Fam. Med. 2017, 18, 153-154. [CrossRef] [PubMed]

106. Nagano, A.; Nishioka, S.; Wakabayashi, H. Rehabilitation Nutrition for Iatrogenic Sarcopenia and Sarcopenic Dysphagia. J. Nutr. Health Aging 2019, 23, 256-265. [CrossRef]

107. Davenport, S.J.; Arnold, M.; Hua, C.; Schenck, A.; Batten, S.; Taylor, N.F. Physical Activity Levels During Acute Inpatient Admission After Hip Fracture are Very Low. Physiother. Res. Int. 2015, 2050, 174-181. [CrossRef]

108. Martone, A.M.; Bianchi, L.; Abete, P.; Bellelli, G.; Bo, M.; Cherubini, A.; Di Bari, M.; Maggio, M.; Manca, G.M.; Marzetti, E.; et al. The incidence of sarcopenia among hospitalized older patients: Results from the Glisten study. J. Cachexia Sarcopenia Muscle 2017, 8, 907-914. [CrossRef] [PubMed]

109. Murayama, I.; Asai, T.; Misu, S.; Yamauchi, M.; Miura, A.; Ikemura, T.; Takehisa, T.; Takehisa, Y. Is increased "stay away from bed" time associated with improved clinical rehabilitation outcomes in Japanese rehabilitation hospitals? A prospective observational study and clinical practice. Aging Clin. Exp. Res. 2019. [CrossRef] [PubMed]

110. Inoue, T.; Misu, S.; Tanaka, T.; Sakamoto, H.; Iwata, K.; Chuman, Y.; Ono, R. Inadequate Postoperative Energy Intake Relative to Total Energy Requirements Diminishes Acute Phase Functional Recovery from Hip Fracture. Arch. Phys. Med. Rehabil. 2019, 100, 32-38. [CrossRef] [PubMed]

111. Foss, N.B.; Jensen, P.S.; Kehlet, H. Risk factors for insufficient perioperative oral nutrition after hip fracture surgery within a multi-modal rehabilitation programme. Age Ageing 2007, 36, 538-543. [CrossRef] [PubMed] 
112. Mudge, A.M.; Ross, L.J.; Young, A.M.; Isenring, E.A.; Banks, M.D. Helping understand nutritional gaps in the elderly (HUNGER): A prospective study of patient factors associated with inadequate nutritional intake in older medical inpatients. Clin. Nutr. 2011, 30, 320-325. [CrossRef] [PubMed]

113. Bell, J.J.; Bauer, J.D.; Capra, S.; Pulle, R.C. Multidisciplinary, multi-modal nutritional care in acute hip fracture inpatients-Results of a pragmatic intervention. Clin. Nutr. 2014, 1-7. [CrossRef] [PubMed]

114. Wakabayashi, H.; Sakuma, K. Rehabilitation nutrition for sarcopenia with disability: A combination of both rehabilitation and nutrition care management. J. Cachexia Sarcopenia Muscle 2014, 5, 269-277. [CrossRef]

115. Maeda, K.; Akagi, J. Treatment of Sarcopenic Dysphagia with Rehabilitation and Nutritional Support: A Comprehensive Approach. J. Acad. Nutr. Diet. 2016, 116, 573-577. [CrossRef] [PubMed]

Publisher's Note: MDPI stays neutral with regard to jurisdictional claims in published maps and institutional affiliations.

(C) 2020 by the authors. Licensee MDPI, Basel, Switzerland. This article is an open access article distributed under the terms and conditions of the Creative Commons Attribution (CC BY) license (http://creativecommons.org/licenses/by/4.0/). 